\title{
Biodegradability of Synthetic Plastics and Polymeric Materials : An Illusion or Reality in Waste Managements?
}

\author{
Elizabeth Ka Wing Wu ${ }^{1}$, Ji-Dong Gu ${ }^{2,}{ }^{*}$ \\ ${ }^{1}$ School of Biological Sciences, The University of Hong Kong, Pokfulam Road, Hong Kong Special Administrative Region, China \\ ${ }^{2}$ Environmental Engineering, Guangdong Technion - Israel Institute of Technology, 241 Daxue Road, Shantou, Guangdong 515063, China
}

\begin{abstract}
Petroleum-based plastics are an indispensable part of our daily life now because they are flexible, convenient, light weight, waterproof, and also have good mechanical strength and economical. They are especially suitable in products packaging, but they accumulate in soils, rivers and oceans, resulting in undesirable environmental and ecological hazards. Conventional plastics wastes in landfills occupy a much higher proportion of space because of their light-weight and extremely low biodegradation rate under anaerobic conditions. Composting is a treatment process to deal with biodegradable plastics (BPs) wastes and diverts a fraction of the wastes from landfilling to provide a feasible solution to the waste management problem. Biodegradability and degradation rate of plastics products depend on the fundamental chemical characteristics of the specific plastics mainly while environmental conditions and the establishment of an active degrading population of microorganisms contribute to a small extent of the fate of plastics after disposal. As the biodegradation rate varies among different plastics, a group of testing methods are available for assessing the degradability of different plastics and their products. Plasticizers in plastics and polymeric materials deserve a special attention up on their dispersal and ecological impact because of their endocrine-disrupting activity. The widely used phthalate esters are biodegradable by indigenous microorganisms in the environments, but the large quantity of them used is a serious issue to the environment and ecological health. However, there is an apparent cost difference between biodegradable and synthetic plastics, which hinder the commercialization of biodegradable ones for daily use. Separation of waste collection and education can contribute to the plastic waste management. It is unrealistic that biodegradable plastics are the solution to the problems facing today's society on waste management. The ultimate goal is to reduce the use by society members so that amount of waste generated can be reduced so that waste products can be reduced from the sources.
\end{abstract}

Keywords: Plastics, biodegradable plastics, landfill, composting, plasticizer, phthalateester, endocrine-disrupting activity

Correspondence to: Ji-Dong Gu, Environmental Engineering, Guangdong Technion Israel Institute of Technology, 241 Daxue Road, Shantou, Guangdong 515063, China; E-mail: jidong.gu@ gtiit.edu.cn

Received: February 19, 2021; Accepted: March 18, 2021; Published Online: March 19, 2021

Citation: Ji-Dong Gu, 2020. Biodegradability of Synthetic Plastics and Polymeric Materials: An Illusion or Reality in Waste Managements? Applied Environmental Biotechnology, 5(2): 34-52. http://doi.org/10.26789/AEB.2020.02.003

Copyright: Biodegradability of Synthetic Plastics and Polymeric Materials: An Illusion or Reality in Waste Managements? @ 2021 Elizabeth Ka Wing Wu and Ji-Dong Gu. This is an Open Access article published by Urban Development Scientific Publishing Company. It is distributed under the terms of the Creative Commons Attribution-Noncommercial 4.0 International License, permitting all non-commercial use, distribution, and reproduction in any medium, provided the original work is properly cited and acknowledged.

\section{Introduction}

Since the invention of plastics, they become increasingly popular and have replaced many traditional materials, namely glass, wood and metals in applications (Lee, 1996a; Gu, 2003a, 2003b, 2017, 2021). This is simply because they are less expensive, more durable and flexible for different application purposes. Petroleum-based plastics are widely used in packaging, electrical appliances and medical purposes (Swift, 1995; Gu, 2003a); they are tailor-made by the chemical structure and composition, and manufacturing processes to attain these satisfactory applications (Swift, 1995). Some characteristics, such as hydrophobicity of waterproof, low density and much more resistance to microbial attack (Shah et al., 2008), are essential characteristics to be used for long-term applications in packaging. Because of their physical properties and flexibility for different applications, it is not surprising that conventional plastics derived from petroleum are ubiquitous in our daily life.

Because of the intensive consumption of plastics, especially in packaging, household appliances, medical uses, and aeroand space applications, they pose serious threats to the environment (Gu, 2020) and ecosystems (Gu, 2017, 2021) through ingestion of plastics products by marine wildlife as an example. Petroleum-based plastic wastes in marine environment have gained much wide attention since 1970's (Anon, 1975; Baird and Hooker, 2000; Carpenter et al., 1972; Connors and Smith, 1982; Derraik, 2002) as they form a large portion of the land-based wastes found in oceans (Laist, 1987; Stefatos et al., 1999). Plastic wastes may come from land, e.g., agriculture, disposal on land without a proper waste collection system (Bugoni et al., 2001; Jones, 1995) or be dumped from land into oceans (Anon, 1975). Ingestion of plastics by marine wildlife is reported widely (Anon, 1975; Baird and Hooker, 2000; Carpenter et al., 1972; Connors and Smith, 1982). They are accidentally ingested because of the confusion of target food items and the floating plastic objects as the colour and size are similar (Gramentz, 1988; Laist, 1987), overlapping of the major feeding area and the distribution of the plastic debris (Laist, 1987), feeding strategies (Moser and Lee, 1992) 
or inexperienced animals. It is suggested that plastics block the intestine of marine organisms (Carpenter et al., 1972; Rothstein, 1973) and finally die (Anon, 1975). In addition, plasticizers leak into the aquatic ecosystems, rivers and oceans, because of contact with water and weathering, and may be assimilated and accumulated by marine organisms (Carpenter and Smith, 1972). Red phalaropes (Phalaropus fulicarius) are found to ingest plastics because they are not selective on food items (Rothstein, 1973). Ingested plastics are believed to cause the low fat deposition in the phalaropes and adversely affect the breeding and migration success of the birds (Connors and Smith, 1982). Entanglement is one of the hazards caused by the plastic debris in the ocean. Marine animals, especially the marine mammals, play with the floating objects (Laist, 1987) because of curiosity, but finally being entangled. The entangled animals will be difficult to catch food and serious injured before drown and dead. The problem is intensified by the discarded fishing gears, which keep catching animals after their service life.

Plastics not only pose threats to wildlife, but also create many waste management problems, mainly because they are consumed at a much higher rate and have a higher volume to mass ratio, hence, occupy a larger share of the space in landfills (Miertus and Ren, 2003). Non-degradable plastics are extremely resistant (or take centuries) to degradation (Swift, 1995) and can stay intact in the environment for many years without any noticeable changes in their chemical structures (Albertsson, 1980 ; Albertsson et al., 1994). However, land space is very limited for landfills particularly for metropolitan cities and in developed countries. It is also problematic to treat the plastic wastes by incineration, as the notorious dioxin, which is a carcinogen (Birnbaum and Fenton, 2003), can be produced during the burning of polyvinyl chloride (Agarwala, 2006; Scott, 2000).

Methods have been adopted around the world to reduce the amount of plastic wastes by reducing and recycling of plastics wastes, for example, banning free plastics bags in the United Kingdom (BBC, 2007, 2008). However, voices are heard that if plastics bags are stopped to give out, the hygienic issues will outweigh the waste problem generated by plastics (Quah and Ong, 2008) and may also lead to an increase of unemployment rate (BBC, 2005). Recycling of plastics is not successful as there is not a profit can be made from the recycling business (Lane, 2003) and waste plastics are usually contaminated (Gross and Kalra, 2002), making the recycling operation more costly and difficult (Agarwala, 2006). Because of the simple fact that daily life cannot be imagined without plastics, research has been conducted to develop biodegradable plastics, which do not persist in the environment after the end of the product life, therefore, they are a logic solution to the waste management problems associated with conventional plastics (Miertus and Ren, 2003; Ren, 2003; Zheng et al., 2005).

\section{Plastics and waste management}

Plastics are polymeric materials with very high molecular weights so that they can be processed to different shapes by means, e.g., injection moulding (Stevens, 2002). There are two types of plastics: thermoplastics and thermoset plastics. The former can be melted and re-moulded by heating and cooling, most of the plastics are of this type, such as polyethylene; the latter, in contrast, cannot be re-shaped once it is moulded for the first time (Stevens, 2002). Thermoplastics can be used for many purposes, range from food packaging, bottles, fish nets, toys, hose and electrical insulation, whereas thermoset can be used in furniture, household appliances and engineering application ones (Stevens, 2002).

Plastics are inexpensive, light, resistance to microbial degradation $(\mathrm{Gu}, 2003 \mathrm{a}, 2017,2021)$ and can be processed into different shapes to fit different purposes. They are used in electronics, medical field, transportation, etc $(\mathrm{Gu}, 2003 \mathrm{a}$; $\mathrm{Gu}$ et al., 2000b). As they are not very expensive, it is not surprising for their popularity in usage as disposable, such as packaging. Polyethylene, polypropylene, polystyrene, polyvinyl chloride, nylons, poly(ethylene terephthalate), poly(butylene terephthalate) and polyurethane are generally used for packaging. The service life of packaging is usually very short and one time only, so the wastes generated from this category are the largest quantities and increasing fast. Conventional plastics are relatively resistance to biological decomposition due to the high molecular weight of C-C bond. As conventional plastics are chemical synthesized and structurally new to nature, there is not enough time for organisms to evolve capability to use them as carbon or energy source (Mueller, 2006; Gu and Mitchell, 2013 ; Gu, 2017, 2021). Its resistance to degradation leads to the accumulation of plastics wastes, and hence the waste management problem plus other ecological issues and hazards (Agarwala, 2006) as mentioned above. As human population increases, more resources and land are required for human use. More resources needed means more wastes will be generated; more land required for human use - generally used for living, agriculture and developments - implies less land is available for any new landfills and landfills also have a limited service life. These two contradictory requirements result in applying the conservation rule of 3Rs: reduce, reuse and recycle.

Waste reduction has been practiced effectively in some developed countries. Plastics utensils are switched to stainless steel in schools of Japan (Stevens, 2002) to achieve plastic waste reduction. Personal utensils are widely adopted to decrease the demands on disposable ones in Taiwan. However, it is not easy for the public to switch from the convenient plastics at large scale because plastics are relatively cheap and can virtually designed for far too many purposes (Stevens, 2002). Replacement of plastics by metals and glass is also problematic, as metals are more expensive at the beginning and glass also fills up the landfill spaces after the service life (Stevens, 2002). Reuse is not feasible for the hygienic reason or sometimes it is not possible to sort the plastics out from agriculture in the case of mulching thin films in the field. Recycling of plastics scraps within factories or recycling of plastics products by the producers have been carried out (Stevens, 2002). Recycling of the post-use plastics requires proper collection and sorting, which are both labour intensive and demanding. Considering the energy used and additives introduced during the recycling process, recycling may be 
considered to be environmentally unacceptable based on economic analysis (Stevens, 2002). Plastics are hardly made of pure resin of any polymers to achieve the commercial products for disposal. They usually contain different additives for different applications, e.g., color, fire retardants, water repellants, antimicrobial, and plasticizers to make the recycling process difficult (Agarwala, 2006). Thermosetting plastics are difficult to be melted and reshaped, so it is not suitable for recycling at all. Thermoplastics can be recycled, but the mechanical properties of plastics become weaker after several rounds of melting and moulding (Stevens, 2002). In view of the recycling of plastics is adopted, Resin Identification Code is used by Society of the Plastics Industry to facilitate the resin identification during recycling. Their logos are stamped or imprinted on the plastics products. Although plastics recycling program is in place in many countries, e.g., the United States, less than $10 \%$ of plastics wastes are recycled (Stevens, 2002).

Even with the application of the 3 Rs, waste will be generated continuously. Incineration may be an option for waste treatment to eliminate them effectively. It is notorious because the emission of dioxins, however, safety level can be attained by state-of-the-art technology (Stevens, 2002) to removal the fear from public. A developing technology of incineration can recycle plastics and provide feedstock to plastics generation (Stevens, 2002). The problem in applying this technology is that plastics are not a good conductor of heat and so require a longer time to be heated (Stevens, 2002). It is difficult for the less developed countries to employ the high technology which is always more costly. Landfill is the final destination of wastes. Plastics occupied a large volume and so shorten the service life of landfills. Landfills have their own environmental problems too, such as leachate contamination of the ground water and methane production - a very powerful greenhouse gas (Jayasekara et al., 2005). Methane produced from landfills may cause explosions (Scott, 2000). Plasticizers accumulate at very high concentrations in the landfill leachate $(\mathrm{Gu}, 2017)$, making treatment difficult in operation. Finding new sites for landfills is problematic in many developed countries as available land is scarce and very expensive. The waste problem caused by plastics leads to the emerging of biodegradation of plastics (BPs), which is considered to be a viable measure to solve the waste management problem (Huang, 1995). The most suitable treatment for BPs is composting which divert wastes from the traditional waste management for landfilling.

\section{Biodegradable plastics and their biodegradation}

\subsection{Biodegradable plastics}

During the development of the BPs, there are three main types of BPs being classified: (1) mixing the natural biodegradable materials, e.g., starch, with the petroleum-based polymers, e.g., polyethylene; (2) incorporating functional groups which is prone to microbial attacks; (3) polymers which are synthesized by bacteria and plants, which are truly biodegradable completely (Huang et al., 1990; Gu, 2003b). There are different meanings of degradable plastics, biodegradable plastic and compostable plastic. Degradable plastics can be decomposed under favourable conditions by physical, chemical and, most importantly, biological means and meet the requirements of the standard testing methods; biodegradable plastic is the plastics degraded by the action of naturally occurring microbes; compostable plastic is the one which is degraded by biological mean at the rate that is comparable to a control material and leaves invisible and non-toxic materials under the composting environment (Greene, 2007; Stevens, 2002; Stevens and Goldstein, 2002). Degradable plastics as commercially labeled may not be biodegradable in reality as the disintegration may not be due to the actions of microorganisms (Stevens and Goldstein, 2002), but it is caused by UV radiation, heat or hydrolysis (Darby, 2012). Compostable plastics are one type of biodegradable plastics (Kyrikou and Briassoulis, 2007); the biodegradation of plastics may be so slow that cannot be called compostable (Albertsson et al., 1994; Stevens and Goldstein, 2002).

The ideal biodegradable plastics should have the required mechanical strength during the service life, and able to be disintegrated in the disposal environment and assimilated by the microbes (Scott, 1999) and leave non-toxic residue after the service period. BPs can be used in crops cultivation, paper coating, medical purposes, toys and packaging (Huang et al., 1990; Scott, 2000; Stevens, 2002). BPs are mainly used for those which needed to be biodegraded and disposed of once it is used. Biodegradable materials can be used in medical threads and drugs, which the former do not require removal operations on the patient and the latter can control the release of drugs. Biodegradable agricultural mulch is preferable as it reduces the cost for collecting it after the cropping seasons and leave non-toxic residue in the soil. It can also form the capsule of fertilisers for agricultural uses, similar to the one used in drugs. Biodegradable plastics waste collection bags are useful for the storage of compostable waste, such as, food waste. The BPs are used increasingly in disposables, such as, mulch films used in agriculture, because of its properties (EB, 2008) The use of BPs can improve the waste management problem without increasing the unemployment rate and sacrificing the social cost (hygiene). In addition to lessen burden to landfills, BPs can also conserve the limited fossil fuel as they are made from renewable sources (Ren, 2003).

While most of the plastics are synthetic, some are naturally occurring (Stevens, 2002). They are formed from the biochemical reactions of the organisms and are called biopolymer (Gross and Kalra, 2002; Stevens, 2002). It is estimated that the bioplastics cover one-fifth of the European plastics market in 2007 and is expected to increase 20\% annually (EB, 2008). Examples are carbohydrates, proteins, polyester and nucleic acids (Stevens, 2002). They are part of the natural nutrient cycle, so they are biodegradable and the biodegradability is largely controlled by the presence of oxygen and nitrogen atoms in the polymer chain (Stevens, 2002). They are extracted from the organisms and then purified (Stevens, 2002). After their service life, they are degraded, usually, by 
composting. The products of the composting include finished compost, water and carbon dioxide (Schroeter, 1998). The compost can improve the soil quality, so it is good for growing plants, which some are used for making BPs. It a cycle as proposed by Schroeter (Schroeter, 1998): plants are used to produce plastics and then they can be used to produce compost, which supports the growth of plants, and the cycle goes on and on. The materials are recovered through the microorganisms' actions.

\subsection{Biodegradation of plastics}

Degradation of plastics is "a deleterious change in its appearance, physical properties, or chemical structure" (Stevens, 2002). Biodegradation is carried out by naturally occurring heterotrophic microorganisms, namely bacteria and fungi, which use polymers as the source of carbon and energy (Gross and Kalra, 2002; Gross et al., 1995; Gu, 1999, 2003a, 2003b, 2012, 2017, 2020, 2021). Under natural condition, microbial biofilm is formed on the surface of polymers first $(\mathrm{Gu}, 2003 \mathrm{a}$, 2012; Gu and Mitchell, 2013 ) before further attack of polymer can take place. The formation of bio-film on a material under moisture conditions involves a series of microbial action steps: (1) the quick formation of organic film, which includes water soluble substances, extracellular polysaccharides and organic metabolites, on the material; (2) microorganisms attach on a specific location on the surface; (3) attachment of organisms may be selective or random; (4) detachment of microorganisms may occur because of the abiotic factor or the choice of the microorganisms; (5) as the population growth and the accumulation of the extracellular polysaccharides, bio-film is formed (Gu, 1999; Gu and Mitchell, 2013 ). This bio-film is responsible for the biodegradation by the action of hydrogen, organic acid or sulphate reducing bacteria by the microorganisms (Gu, 1999, 2012; Gu and Mitchell, 2013 ). Bio-film formation is critical to the later biodegradation.

Decomposition of BPs may involve an initiate breakdown, called depolymerization, of plastics into smaller pieces by physical force and chemicals (Kyrikou and Briassoulis, 2007; Gu and Mitchell, 2013 ). Plastics biodegradation is initiated by the colonisation of microorganisms and then the polymers are degraded by extracellular and intracellular depolymerases. Polymers are usually too large in terms of molecular weight to be directly taken into the cells for bioassimilation. Extracellular enzymes are secreted to cut the polymer to be small enough that is able to be carried across the cell membrane and bring it into the cell where mineralization takes place (Mecking, 2004). Mineralization is the degradation of organic material to inorganic products. The reaction of extracellular enzymes takes place on the surface of the plastics called surface erosion (Sartorius, 2003). The polymer may be cut within the polymer chain or at the ends, which are accomplished by endoenzymes and exoenzymes respectively (Kyrikou and Briassoulis, 2007; Stevens, 2002). The breakage of internal linkage leads to the faster decrease in molecular weight, whereas the sequential breakdown of linkage results in slower fragmentation (Kyrikou and Briassoulis, 2007). The water soluble and smaller intermediates are brought into the cell and metabolized. The enzymes of the microorganisms convert the BPs to carbon dioxide, methane, water, humic matter and other substances (Gross and Kalra, 2002). The stage of breaking polymers down is the rate-determining factor in general (Mueller, 2006; Gu, 2003a, 2012; Gu and Mitchell, 2013 )(Figure 1). The responsible group of microorganism and degradation pathway depends on the oxygen level. In the presence of oxygen, aerobic degradation is carried out and produces carbon dioxide and water; anaerobic degradation is carried out under the absence of oxygen, methane, carbon dioxide and water will be produced (Gu, 2003a; Stevens, 2002; Gu and Mitchell, 2013 ).

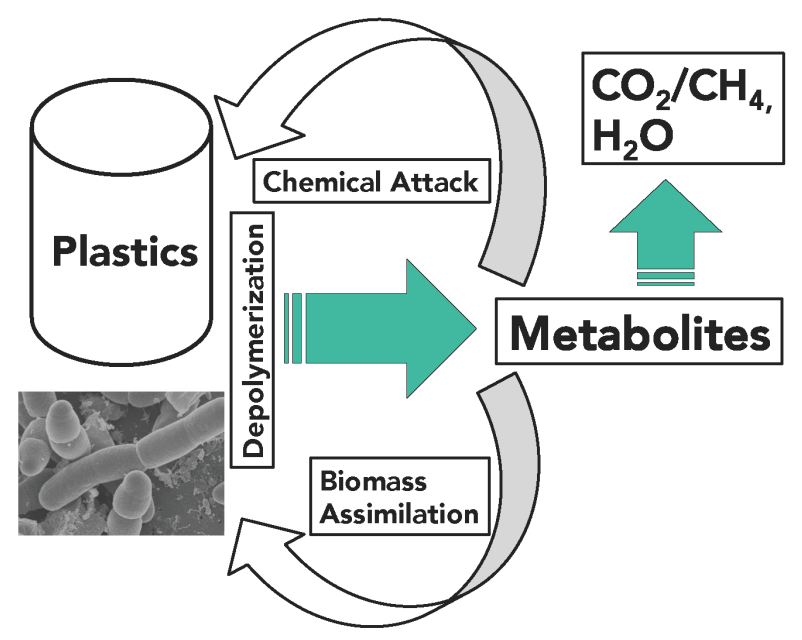

Figure 1. A simplified illustration on microbial degradation of plastics and the general mechanism involved and the end products produced

The rate of plastics biodegradation in soils depends on the chemistry of the plastics and also the environment. For chemistry, the molecular weight and composition are main key factors. Additionally, others include temperature, availability of water and oxygen, $\mathrm{pH}$, pressure, surface area of substrates and the establishment of the responsible microorganisms (microorganisms which possess the suitable enzymes). Life on the Earth depends on the metabolism and it is not surprising that the biodegradation is slow under low temperature as metabolic rate decrease with temperature. Moisture is important too as microorganisms need bioavailable water to survive and it is required for hydrolytic depolymerization and degradation (Kyrikou and Briassoulis, 2007; Stevens, 2002; Gu, 2003a, 2017; Gu and Mitchell, 2013 ). Energy yield is higher under aerobic condition and support more microbes $(\mathrm{Gu}, 2003 \mathrm{a}$, $2017,2020,2021)$. Oxygen is the electron acceptor under aerobic conditions, while nitrate, sulphate, ferric iron, manganese and bicarbonate are the electron acceptor under anoxic conditions (Kyrikou and Briassoulis, 2007). The most important is to provide optimum conditions for the growth of the responsible microorganisms, so that the microorganism can grow healthily and degradation can be maintained.

In addition to the action of the extracellular enzymes, the physicochemical reactions, such as, the oxidation, photochem- 
ical reaction and hydrolysis, can also cut the long polymer chain into smaller pieces (Sartorius, 2003). The biodegradability of polymer decreases with an increase in molecular weight in general (Gu, 2003a, 2017, 2020, 2021). Polymers with higher molecular weight are relatively difficult to be biodegraded because they are not water soluble and too large to pass through the cellular membrane for assimilation (Shah et al., 2008). As discussed above, water is essential in hydrolytic reaction, whether the plastics contain the hydroxyl groups ($\mathrm{OH})$ or not are also important. The hydroxyl groups can form hydrogen bond with the water molecules and encourage the hydrolytic degradation (Stevens, 2002). The solubility in water also help the transfer of polymer through the cell membrane (Gu, 2003a). The solubility of polymers can be improved by the addition of hydrophilic (water-liking) group (Freier et al., 2003). When the polymer chain is cut to small enough, mineralisation can be carried out inside the microorganism cells. The chain branching, stereochemistry and crystallinity are also important (Gu, 2003a, Kyrikou and Briassoulis, 2007; Stevens, 2002; Gu and Mitchell, 2013 ; Zheng et al., 2005). The first two determine the plastics degradability by specific enzymes to the substrates concerned (Stevens, 2002). Crystallinity can determine the oxygen penetration, i.e., oxidation, and penetration by water, i.e., hydrolytic degradation (Stevens, 2002).

Research is conducted to check if BPs can be biodegraded in landfill conditions (Ishigaki et al., 2004). Polyhydroxybutyrate-co-valerate (PHBV) is studied if there is any difference in biodegradability under aerobic and anaerobic landfill conditions. PHBV film is found to be degraded almost completely under simulated aerobic landfills within four months based on the analysis on weight loss and appearance whereas there is no significant degradation happened under anaerobic conditions. Polycaprolactone (PCL) is degradable faster under anaerobic condition, although the rate is not as fast as PHBV. Biodegradability of BPs in landfills is determined by different types of BPs and oxygen content in the landfill reactors. To make BPs able to be degradable in landfills, it may involve intensive management (e.g. aeration) and maintain conditions, which favour the biodegradation of different BPs.

Biodegradation is reported in polyethylene with pro-oxidant additives (Albertsson et al., 1994; Jakubowicz et al., 2003). The additives promote the oxidation, so the molecular mass of the polymer is reduced to be small enough to allow intracellular mineralisation to take place. In a study, the rate of reduction in molecular mass by oxidation increases with the increase of temperature, and reach the highest at $70^{\circ} \mathrm{C}$ (Jakubowicz et al., 2003). The mineralization reaches $60 \%$ within six months in the study and suggested that it is increasing and will eventually being bioassimilated completely. However, the mineralisation reaches plateau after six months and there should be accumulation of plastic residue occurs. Biodegradation of low-density polyethylene, which is buried in the soil over 32 years, is also reported, clear whitening and holes are recorded (Otake et al., 1995). Other synthetic polymers (polystyrene, polyvinyl chloride and urea formaldehyde) do not bear significant signs of biodegradation even they have been buried in the soil for appropriately the same period of time (Otake et al., 1995). It is suggested that some additives promote the abiotic degradation and followed by biodegradation, which convert the abiotic degradation products to carbon dioxide, water and biomass (Albertsson et al., 1994).

It is worth to mention that the initial shortening of polymer chains may be initiated by other abiotic factors, like, heat, UV radiation, oxygen and moisture. The stage of polymer shortening can be called degradable stage, but not biodegradable until the microorganisms step in (Mohee et al., 2007). Biodegrada-

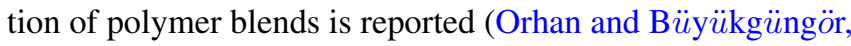
2000; Ratajska and Boryniec, 1999; Gross et al., 1995; Gu et al., 1993a, b, c, 1994). The rate of biodegradation of conventional plastics blends in soil is faster than that in water (Ratajska and Boryniec, 1999). The natural polymers are degraded first and holes are form on the plastics sheet. Microorganisms are believed to carry out the degradation through the holes. Polyethylene is reported to be degraded in mangrove soil (Kathiresan, 2003), the responsible species include bacteria and fungi. The degradation rate reaches about $4 \%$ in nine months in situ. The degradation is achieved by UV radiation, and microbes are also believed to be responsible too as proved from the laboratory test.

The microbial species isolated include Pseudomonas sp., Staphyloccocucs sp., Moraxella sp., Micrococcua sp. and Aspergillus spp.. Biodegradation of polyethylene is also reported in other studies and is first degraded abiotically to reduce the molecular mass (Agamuthu and Faizura et al., 2005; Bonhomme et al., 2003; Mohee and Unmar, 2007; Gu and Mitchell, 2013 ; Gu, 2017, 2020). It seems that the biodegradation of polyethylene reported is actually degradation of the additives and plasticizers (Mohee and Unmar, 2007; Gu, 2012, 2017; Gu and Mitchell, 2013 ). Polymers are not easy to be metabolised by bacteria unless another source of carbon and energy present to support growth (Gu et al., 2000a; Gu, 2017 , 2020). However, caution must be taken on whether the biodegradation is taken place on the blends, additives or on the conventional polymers themselves.

\subsection{Examples of Biodegradable plastics}

BPs can be made from renewable (carbohydrates and polylactic acid) or non-renewable materials (polyvinyl alcohol and polycaprolactone) (Darby, 2012; Kyrikou and Briassoulis, 2007). It is estimated that the production process consumes $30-50 \%$ less of fossil fuel with the use of renewable materials for the production of BPs (Darby, 2012). Renewable materials for the production of BPs can be obtained through direct extraction of polymers, e.g., protein, cellulose, starch; chemical process, e.g., polylactic acid; and fermentation, e.g., polyhydroxyalkanoates (PHA) (Miertus and Ren, 2003).

\subsubsection{Polyhydroxyalkanoates (PHA)}

PHA is one of the polyester and can be found in the cytoplasm of bacteria (Mecking, 2004; Stevens, 2002). It is the energy and carbon sources of bacteria under the carbon stress 
(Stevens, 2002). PHA is produced by bacteria under unfavorable condition (limited supply of nitrogen or phosphorus) with the supply of carbon source and can be used when the environment is recovered (Koller et al., 2008). It is a potential material to be used to make plastics of thermoplastics characteristics (Lee, 1996b). Polyhydroxybutyrate (PHB) is the simplest and commonest form of PHA (Freier et al., 2003; Stevens, 2002). Carbohydrates for PHA production include carbohydrates, propionic acid, whey and methane (Lee, 1996b; Reddy et al., 2003). Different carbon sources can produce different PHA by fermentation, such as PHB is produced when glucose or sucrose is fed to the microbes (Stevens, 2002). During microbial biosynthesis of PHB by Rastonia eutropha, the carbon substrates are converted to acetyl-CoA through metabolism. Two acetyl-CoA are condensed to acetoacetylCoA by an enzyme called 3-ketothiolase. Acetoacetyl-CoA is reduced to R-(-)3-hydroxybutyrl-CoA by the enzymatic action of acetoacetyl-CoA reductase. R-(-)3-hydroxybutyrl-CoA is polymerised by PHA synthase to form PHB. A schematic pathway of the biosynthesis of PHB is shown (Figure 2). Many microorganisms can produce PHA, but only a few is selected for the production because not all of them possess the ideal production requirements. The selected species should be able to grow to high population with high PHA yields, non-toxic to the environment, able to use inexpensive carbon substrates, allow easy extraction and produce the required polymers (Chen, 2003; Lee, 1996b; Ojumu et al., 2004). Those bacteria selected for PHA production are comprised of Alcaligenes latus, Azotobacter vinelandii, Pseudomonas oleovorans and Rastonia eutropha (formerly called Alcaligenes eutrophus) (Chen, 2003; Lee, 1996b). The screening process of the desirable species involves the isolation and growth of population, extraction of PHA and then investigation on the types of PHA produced. These processes are lengthy and cost demanding. Nile red method and FT-IR method are used for the screening of the PHA producing microbes. Nile red can stain the PHA granules to provide a quantitative determination of PHA production (Chen, 2003). The limitation of this method is that it cannot recognize the structure of the synthesized PHA (Chen, 2003). FT-IR can provide both the quantity and type of PHA synthesized (Chen, 2003).

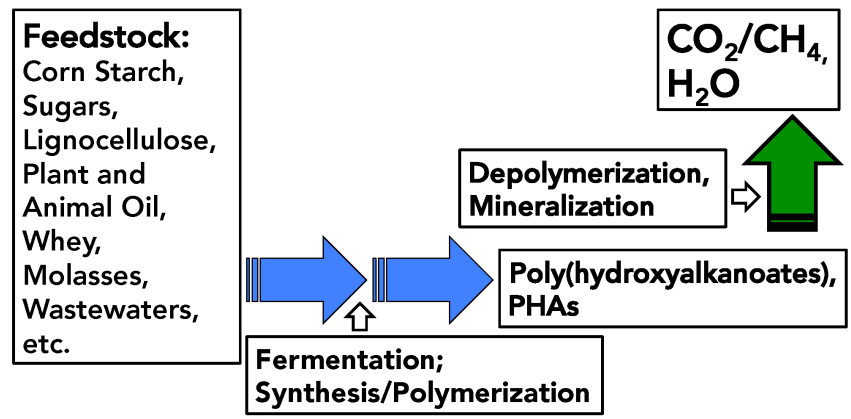

Figure 2. A flow chart showing the synthesis of biodegradable polyhydoxyalkanoates (PHAs) from various natural materials by microbial polymerization from feedstock and the complete degradation by microbial depolymerization
At the beginning of the cultivation, bacteria are allowed to grow under supply of nutrients; later, nutrient will be supplied in limit to allow the accumulation of PHA (Lee, 1996b). During the period of nutrients limitation, the bacteria will not grow but only produce and accumulate PHA. PHB can accumulate up to $80 \%$ of the cell dry weight at the end of the fermentation period (Luzier, 1992). Extraction of the PHA involves the breakdown of cell. PHA is obtained by centrifuge, organic solvents (Mecking, 2004; Verlinden et al., 2007) or aqueous solution. Aqueous solution extraction is less expensive but lower the molecular weight of the polymer by $40 \%$ (Luzier, 1992). Organic solvent, such as, chloroform and methylene chloride, extraction has safety concern (Luzier, 1992). Extraction by organic solvent is more expensive because this process involves the use of a large amount of organic solvent (Lee, 1996a).

PHA can also be produced by genetically modified plant (Scott, 2000). Genes (responsible for the PHA production) of $R$. eutropha is integrated in a transgenic plant and PHA of $14 \%$ of dry weight is obtained (Lee, 1996a). The PHA content can be increased through this technology, but it is not guaranteed that the supply can meet the market need even with the increase in PHA yield (Scott, 2000). Oilseed plants are potential candidates for PHA production as both PHA and oil are produced from acetyl-CoA, so they are potentially able to genetically modify for the PHA production (Reddy et al., 2003). PHA synthetic strains can be found in the activated sludge (Kumar et al., 2004; Yan et al., 2008). Twelve PHA accumulating strains are isolated from the municipal wastewater activated sludge in one research, most of them are gram negative and the PHA content can reach about $25 \%$ of cell dry weight at maximum (Yan et al., 2008). This is suggested to be an economically viable method of PHA production (Yan et al., 2008). In order to reduce the cost of production, PHA can also be produced by genetically modified bacteria: genes for using cheap carbon substrates are incorporated into the PHA producing bacteria or incorporating the PHA producing genes into the non-PHA producing bacteria but able to use cheap carbon substrates (Reddy et al., 2003). The cell membrane of natural PHA synthesis bacteria is usually difficult to be broken, and hence, the extraction is difficult and costs more money. E. coli, however, can grow fast, able to use cheap carbon substrates and its membrane is easily to be broken and will lower the production cost if it was able to synthesise PHA. By introducing the $R$. eutropha PHA synthesis genes into $E$. coli, this can reduce the production cost.

Biodegradation of PHA is the same as described in Section 3.2. PHA polymers are broken down by extracellular enzymes into hydroxyacids (Reddy et al., 2003). PHA can be degraded under a wide range of temperature (Reddy et al., 2003); like others degradation process, carbon dioxide and water are produced under aerobic condition, while carbon dioxide and methane are produced under anaerobic environment. Most of the PHA degrading microorganisms produce one PHA depolymerase (Shah et al., 2008), but one species Pseudomonas lemoignei can produce at least seven extracellular depolymerases which can digest $\mathrm{PHB}$, poly(3-hydroxybutyrate-co- 
3-hydroxyvalerate) [P(3HB-co-3HV)] and PHV (Shah et al., 2008). PHBV degradation was detected in a simulated landfill by $60 \%$ of weight after 11 months and also under strictly anaerobic conditions (Luzier, 1992; Gross et al., 1995; Gu, 1994).

PHB is water proof and not soluble in water and different from other biodegradable polymers (Ojumu et al., 2004). PHA possesses mechanical strength, which can be comparable with the conventional plastics, but its characteristics can be modified by linking with different monomers (Slater et al., 2003) or adding conventional additives (Luzier, 1992). PHA can be used to make the coating on paper, bottles and disposable products (Lee, 1996b). As the application of BPs involve packaging and medicine, it is very significant that they are non-toxic. The presence of poly(3HB), a member of PHA, in human bodies and many other organisms shows the fact that it is not toxic (Lee, 1996a).

\subsubsection{Biodegradable plastics on the market}

Poly(3-hydroxybutyrate) and $\mathrm{P}(3 \mathrm{HB}-\mathrm{co}-3 \mathrm{HV})$ are produced commercially at present (Lee, 1996b). PHA is sold on the market, but the price is about 16 times of polypropylene (Lee et al., 2003; Lee, 1996b). Imperial Chemical Industries (ICI) in the United Kingdom produced PHBV by fermentation and sold it under the brand name BIOPOL. The production is made by $R$. eutropha and using glucose as carbon sources. In the United States, industries, like Procter and Gamble, cooperated with the University of Massachusetts at Amherst to study the BPs (Shah et al., 2008). BIOgroupUSA sells biodegradable and compostable plastic products, which are made from cornstarch. In India, Om Bioplast Ltd produces photo-biodegradable from carbohydrates.

\section{Legislation of biodegradable plas- tics}

There is a need to have some measures, such as label system and legislation, to promote and support the development and commercialization of BPs. Legislation can stimulate (or force) the use of BPs. Label system allows the manufacturers to standardize the quality of the BPs in the market produced according to one or several standards. Standards are needed for the clarification of terms and standardize the degree of biodegradability can be called biodegradable. The labelled BPs can facilitate the materials recovery processes. BPs have to be collected for a different treatment from the main waste treatment stream, so that they can receive appropriate treatment and useful material can be recycled, more importantly, this can lower the burden to the landfill. As it is difficult to distinguish between the conventional plastics and the BPs from their appearance, there is a need to have a label system to facilitate the sorting. The label system can also ensure that the products, by passing one or more standards, are truly compostable and not making marketing gimmick.

\subsection{Legislation}

It is suggested that the price of BPs is failed to be set by the free market, and legislation has to step in (Swift, 1995). The green technologies usually need the legislative support in less developed countries (Ren, 2003). For example, in Germany, compostable waste charged less for disposal, which favours the development of BPs (Mecking, 2004). Certification and testing methods are available for the decision makers to formulate laws and, hence, affect the purchasing decisions (Stevens and Goldstein, 2002). Laws in less developed countries usually only state the theories, but not practical enforcement, like timetable for implementation; whereas incentive tools and public engagement are usually incorporate in the laws in developed countries (Ren, 2003). Prior to the 2008 Olympics to be held in Beijing, the city publicized the implementation of biodegradable plastics in disposable materials and fast food packaging so that the event should be green. Non-degradable plastics are still a serious headache to the municipal waste management and disposal even today.

"European Parliament and Council Directive 94/62/EC of 20 December 1994 on packaging and packaging waste" (https://www.legislation.gov.uk/eudr/1994/62/contents) regulates the after-use fate of biodegradable packaging and emphasise the biodegradability of it. It states that the biodegradable packaging should be separated from the main waste stream and it should be able to be decomposed to carbon dioxide, water and biomass. "European Parliament and Council Directive 1999/31/Ec of 26 April 1999 on the landfill of waste" (http://eurlex.europa.eu/LexUriServ/LexUriServ.do?uri=OJ:L:1999:18 2:0001:0019:EN:PDF) set targets on reducing the amount of biodegradable municipal waste for landfilling within specific timeframe. Ordinance on Biowaste (BioAbfV) suggests that the biodegradable products have to be collected separately and have to be made from renewable materials, and their biodegradability has also to be tested according to the standard tests. Under these two ordinances, BPs have to be manufactured mostly or completely from renewable resources. This results in unfair market preference of renewable over the non-renewable feedstock.

\subsection{Standardization of biodegradable plastics}

Biodegradation of low-density polyethylene is reported (Otake et al., 1995), but as the rate is so slow (over 32 years in the study) that the accumulation of the material occurs (Zee, 2003) and cannot be called "biodegradable". Some plastics claimed to be biodegradable, but it only mixes with some biodegradable materials, such as starch; the biodegradable portion is degraded, but the non-biodegradable portion remains. This type of plastics is hardly to be considered to be compostable or biodegradable. The compostability of BPs is very important in waste collection and sorting, such as, biodegradable plastic bags are used to store the compostable waste, e.g. food waste and process of picking out the non-biodegradable elements can be omitted. To prevent confusion, there are some standards for how compostable of a BP can be called 
Table 1. Standard methods and practices available for testing degradability of plastics products

\begin{tabular}{|c|c|}
\hline ASTM D5338 & Standard test method for determining aerobic biodegradability of plastic materials under controlled composting conditions \\
\hline ASTM D5929 & $\begin{array}{l}\text { Standard test method for determining biodegradability of materials exposed to municipal solid waste composting conditions by compost } \\
\text { respirometry }\end{array}$ \\
\hline ASTM D5988 & Standard test method for determining aerobic biodegradation in soil of plastics materials or residual plastic materials after composting \\
\hline ASTM D6400 & Standard specification for compostable plastics \\
\hline EN 13432 & $\begin{array}{l}\text { Packaging - Requirements for packaging recoverable through composting and biodegradation - Test scheme and evaluation criteria for } \\
\text { the final acceptance of packaging }\end{array}$ \\
\hline EN 14045 & Packaging - Evaluation of the disintegration of packaging materials in practical oriented tests under defined composting conditions \\
\hline EN 14046 & $\begin{array}{l}\text { Packaging - Evaluation of the ultimate aerobic biodegradability and disintegration of packaging materials under controlled composting } \\
\text { conditions - Method by analysis of released carbon dioxide }\end{array}$ \\
\hline EN 14995 & Plastics - Evaluation of compostability - Test scheme and specifications \\
\hline ISO 14855 & $\begin{array}{l}\text { Determination of the ultimate aerobic biodegradability of plastic materials under controlled composting conditions - Method by analysis } \\
\text { of evolved carbon dioxide }\end{array}$ \\
\hline ISO 16929 & Plastics - Determination of the degree of disintegration of plastic materials under defined composting conditions in a pilot-scale test \\
\hline ISO 17088 & Specifications for compostable plastics \\
\hline
\end{tabular}

compostable. The compostability is determined by standard testing methods within a required period of time under specified conditions (similar to the waste disposal environment) (Swift, 1995; Zee, 2003). Testing is needed to judge if there will be toxic residue after degradation (Stevens, 2002). Tests should be conducted in certified laboratories. European Committee for Standardization (CEN), International Organization for Standardization (ISO) and American Society for Testing and Materials (ASTM) are some organizations to establish standard for the testing methodologies. European organization, CEN, intends to provide standards for their Member countries to facilitate the trade between them (CEN, 2009). Individual European country has her own organization for standards, such as Germany has the German Institute for Standardization (DIN). ISO is also providing international standard. ASTM is originated in the United States and is an organization to formulate testing methods, definitions and standards for different materials (Stevens, 2002). A list of standards related to compostable plastics is shown in Table 1 .

One can be called biodegradable plastics have to be degraded substantially to the degree that they cause no harm to the environment within a certain period. Biodegradability can be assessed by the carbon dioxide emission, molecular weight and its distribution, biochemical oxygen demand and ecotoxicity (Gu, 2012, 2017; Gu and Mitchell, 2013 ; Gu and $\mathrm{Gu}, 2005$; Kyrikou and Briassoulis, 2007).

Biodegradability can be tested based on the emission of carbon dioxide, which is described in the standards pr EN 14046:2000 and ISO 14855:1999 (Zee, 2003). Comparison of carbon dioxide emitted between the testing sample and the control samples give an idea on the extent and rate of biodegradation. The sample is put into a reactor under suitable condition (temperature, oxygen level and moisture) with nutrient and microbes (in the form of compost) (Zee, 2003). The carbon dioxide, which is emitted because of the respiration of the microorganisms, is recorded and used to calculate the level of biodegradability (Zee, 2003). Pure cellulose is used as a control. EN 13432 states that the level of carbon dioxide emitted of the sample has to be at least $90 \%$ of that of the control within six months (Zee, 2003), while ASTM D6400-99 states that the carbon dioxide emission has only to reach $60 \%$ within the same period of time.

Pr EN 14045:200 and ISO 16929:2000 specify the testing method for examining the degree of disintegration (Zee, 2003). Disintegration test ensures the tested and passed materials leave non-visible sized pieces. The sample is treated under the suitable conditions (temperature, oxygen level and moisture) with some organic waste (sources of in situ microbes). Temperature is measured to monitor if the temperature in the reactor is suitable for the microbial activities, appropriate measures (e.g. cooling) will be taken when necessary. After 12 weeks, the residue in the reactor will be taken out and pieces of materials bigger than $2 \mathrm{~mm}$ will be selected out by sieving to determine the level of disintegration (Zee, 2003). The residue left cannot be more than $10 \%$ according to EN 13432 and EN 14995.

The quality of the final compost produced from BPs is also very important as the quality will determine the health of the vegetation when the compost is applied, and hence, the market of the compost produced. Parameters, such as, nutrient level and $\mathrm{pH}$, are measured and compared with the control (Zee, 2003). EN 13432 states the steps to test the effect of the final compost produced on the germination and growth of plants (Zee, 2003). It also states the permitted concentration of heavy metals in the compostable package (Degli, 2003). This can ensure that the compost produced by the sample do not contain anything poisonous to the vegetation or the environment (Zee, 2003).

There are slight differences between the standards from different organisations. For example, the degree of biodegradability is determined by the relative amount of carbon dioxide emitted measured to the control in ASTM, whereas exact percentage is required under DIN (Stevens, 2002).

\subsection{Label system for biodegradable plastics}

Label system is not just issuing the logo to the manufacturers; good communication among the local governments, waste management agents and customers, producers and users of the composts is essential to establish the label system (Zee, 2003). Labels are issued after the sample is being tested with the required standard methods. They are essential in distinguish- 
ing truly compostable products from claimed compostable products - which have not been tested. The label is printed on the products for easy recognition. The logo can provide choices to the customers to choose a more environmentally friendly product and indicate that the labelled products should be disposed for different treatment (Reske, 2003). There is no significant difference in appearance between the conventional plastics and compostable plastics, the labels are essential for identification. As in the same case of testing methodologies, there are several existing label systems.

\subsubsection{Seedling in Germany}

The label system is originated in Germany and is funded by the German government and European Bioplastics (formerly called Interessegemeinschaft Biologisch Abbaubare Werkstoffe (IBAW)) (Zee, 2003). The manufacturers who want to sell their products advertised as "compostable" or "biodegradable", the products have to be tested with EN 13432 or EN 14995 first. The certification for the logo does not only standardise the polymer to be compostable, but also other components of the products, such as, inks. The test results are sent to the accreditation bodies for approval; if the products contained certified component, testing can be omitted, but the characteristics of the others components have to be listed out for approval by experts (EB, 2009b). Checking on the products will be carried out to ensure the conformity to the criteria. European Bioplastics aims to promote the one-logo-system in Europe and also gets agreement with USA, Japan and China for the recognition to the label to facilitate the trade $(\mathrm{EB}$, 2009a). The labelling system is used in Germany, Switzerland, the Netherlands, Poland and the United Kingdom.

\subsubsection{OK Compost in Belgium and France}

OK Compost logo ensures that the labelled products are able to compost under conditions of composting plants. OK compost Home logo is for those products which can be composted in the household compost bins and can be broken down within 4 months under suitable condition. The system fit the aim for compostable waste storing bags and is adopted by Belgium and France (Zee, 2003). Under this system, not only plastic is registered, one out of 14 is paper (Zee, 2003). The label is based on the draft version of the EN 13432, which is different from its final version, i.e., different from issuance criteria of the Seedling logo (Zee, 2003). Vinotte Academy is the testing and accreditation body.

\subsubsection{BPI logo in USA}

In the United States, the Biodegradable Products Institute (BPI) and the United States Composting Council establish the BPI logo system. This system is based on the ASTM D6400 or D6868 testing method. Labels can be issued to all materials which pass the mentioned tests. Labelled products represent the compostability and no toxic residue left after composting under managed composting facilities, but not the home composting bins.

\subsubsection{GreenPla in Japan}

GreenPla label is issued to those polymers made from natural polymers and pass the required tests. Tests include testing on the degradability and the toxicity of the compost. Applicants for the label carry out the degradability test by following either the ISO 16929 or ASTM D5338 (JBPA et al., 2007). Preparation of the testing samples has to follow ASTM D6400 if ASTM D5338 is followed. If the former testing method and sample net are chosen, the net has to be non-biodegradable plastics with melting point higher than $120^{\circ} \mathrm{C}, 1 \mathrm{~mm}$ mesh size and at least $20 \mathrm{~L}$ at volume. Test on the compost has to be conducted to check the toxicity of the compost produced. The test can either follow OECD Chemical Guideline 208, which at least two out of three categories from the Guideline, or Plant Tests Using Komatsuna (Brassica rapa var. pervidis) from General Administrative Agency Bulletin No. 5005 (Silkworm Farming). Japan BioPlastics Association (formerly called Biodegradable Plastics Society) is the accreditation body. GreenPla labelled products can be composted with other organic waste.

As exemplified by the testing methods and label systems, they are both developed in different countries and by different organisations. The problem is that when a producer sells its products in different countries or wants to register its products for more than one label, one product has to pass different tests and go through several registration processes. It is very time and labour consuming. It is hope that there will be an umbrella system set up to include different label systems, so that once a product is registered to this umbrella system, it is registered to all these systems and reduce the cost to register to different system repeatedly. BPI and DIN have mutual acceptance since 2001; in mid-2001, BPS and BPI cooperate to development test for biodegradable plastic products (Zee, 2003). Alternatively, a consistent and internationally accepted standards and logos should be formed to reduce the troublesome to register for different standards (Jayasekara et al., 2005).

\section{Biodegradable plastics and waste management}

One of the waste management problems that we are now facing is the limited space left in landfill, especially for those small countries or cities, plus the associated environmental problems raised by all available waste treatment methods. There is a need to search for methods to divert waste from landfills and to treat them in a relatively more environmentally friendly way. It should be noted that post-use BPs can be recycled (Cox, 1995) and treated through traditional methods, namely, incineration and landfilling. BPs have similar calorific value as other waste and can be burnt. Composting provides an alternative way for waste treatment. It is worth to highlight again that biodegradable is different from compostable plastics: compostable plastics are those, which can biodegrade faster under specific conditions. Standard testing and certification to labels are significant to ensure the compostability and safety of the products. BPs and labelled products are able to 
help in waste management.

The conventional plastics are not biodegradable and will deteriorate the quality of the compost produced from the post-use treatment of compostable plastics. The sorting of the conventional plastics and compostable plastics is essential, so that the compost production will not be contaminated by the presence of petroleum based plastics; whereas the compostable plastics will not go into the main waste treatment stream - landfills as the final destination - which is not going to lessen the burden to the landfills and cannot receive appropriate treatment. Composting provides compost as an end-product, which is useful fertiliser and should not be wasted. The application of compost can also reduce the use of pesticides (LCSD, 2005). Animal manure, food waste, paper, wood, leaves, biodegradable plastics etc. can be the materials for composting (EPD, 2006; Körner et al., 2005; LCSD, 2005), hence, compostable plastics can be treated simultaneously with other organic waste. Compostable plastics can eventually leave non-toxic materials through the actions of microorganisms, if appropriate conditions (temperature, water content and $\mathrm{pH}$ ) are provided to the microbes in the composting reactors.

BPs can be used to make agricultural covers and collection bags for biowaste. Plastic covers are used in crops growing as they can increase the yield, use less pesticides, reduce temperature fluctuation, lower water evaporation and control weeds (Kyrikou and Briassoulis, 2007; Wang et al., 2004). These improve the growth of crops and are important as the crop growing is intensive nowadays. The problem raised by the non-biodegradable plastics mulch is that the residue left after one growing season is difficult to be collected and will accumulate in the fields. The accumulation of plastics debris spoils the quality of soil, and thus, the productivity of crops in the coming season (Stevens and Goldstein, 2002). In addition, the harvesting of crops is done by machinery in the intensive farming practice, the plastics residue clogs the farm machinery during harvesting. Collection of the plastics debris is labour intensive and time consuming. Even if the residue is collected, it is not possible to be recycled as it is contaminated with other chemicals, e.g., pesticides and fertilisers. Landfilling or incinerating the residue increase the burden of landfills and produce unwanted air pollutants. With the use of BPs as the agricultural mulch, the residue is not required to be removed, which reduce the labour cost, and will be biodegraded. A study is conducted to test if the performance of biodegradable plastics mulch is different from the conventional one; the result shows that the performance of biodegradable one is not significantly different from the conventional agricultural mulch in term of the yield, keeping temperature and moisture (Wang et al., 2004). The biodegradable plastics mulch, like other BPs products, should be programmed to remain intact during the growing period and bioassimilated after the growing season without leaving toxic materials (Scott, 2003). The biodegradable mulch should be designed according to the local climate, as the rate of biodegradability should be different in different areas because it is depends on the conditions of the ambient environment.

Compostable plastics can be used as the collection bags or packaging for organic waste. The Kassel Project (see above) showed that it is feasible to treat compostable plastics with organic waste and do not spoil the compost quality. Composting is implemented or encouraged in many countries, e.g., New Zealand and some of the member countries in European Union. Compostable plastic bags help in storing the organic, i.e., compostable, waste for composting, so that the debagging is not required (Stevens, 2002). Over half of the plastics waste is in the municipal solid waste source in the Western Europe and packaging is half of the total plastics waste produced globally (Stevens, 2002). The use of compostable packaging also does not require the removal of packaging as in the case of conventional plastic packaging being used and reduce the chance of getting low quality compost. During the collection of waste, although the mixing of conventional plastics and compostable plastics can lower the cost of sorting, the existence of conventional plastics deteriorates the quality of the compost produced (Cox, 1995). It cannot be denied that the composting would be facilitated by the prior separation from the waste, which cannot be composted. Therefore, the composting needs to be facilitated by a flawless waste sorting and collection network.

\subsection{Kassel Project}

As the BPs are believed to be able to alleviate the waste management problem, there is a project held in Kassel (Germany) to investigate the feasibility to commercialise and recycle the compostable packaging. This project was held from May 2001 to November 2002 , the subjects being investigated are those packaging bears the label of compostable plastics. This labelling system was just introduced in Germany at that time and a series of promotion campaigns were accompanied with the introduction. Promotions include activities and posters in schools, shops and other public places, and house-to-house fliers. The information is also put on the internet and in the other media.

Two surveys are conducted in September 2001 and at the end of the program. Interviewees were asked about if they had knowledge to the composting label, if they were more willing to use compostable packaging and given that they would cost more, and investigated the preference to compostable packaging of the customers. More than $80 \%$ of the interviewees knew that the hexagon label is the label for the compostable plastics, which suggested that the intensive promotion and the simple symbol are effective. Nearly $90 \%$ of interviewees were willing to use compostable packaging instead of the conventional packaging. $75 \%$ claimed that they would or might pay more for the compostable packaging. The sale of compostable packaging was found to be more demanding than the conventional plastic packaging, especially for those organic crops packaging.

The recovery rate, processing in the composting plant and the safety issue of using compost are found out in this project as well. Bio-waste bins were distributed in Germany for storing the compostable. The recovery rate in those bins varied within urban areas and average at around $65 \%$. There was 
at most $2 \%$ of non-compostable found in the bio-waste bins. In the composting plant, non-compostables were selected out manually (as the logo had to be identified by human). The success in selection is determined by the rate of delivery belt and the percentage of impurities in the waste. As the appearance of conventional plastics and compostable plastics is similar, it is easily to be confused if the delivery rate is too high and the waste contains too many impurities. The quality of compost was tested on Chinese cabbage. The yield is concluded to be not significantly different from those using the control compost.

The program organisers suggest that the findings are promising. The initial high cost of compostable plastics should be compensated by the advantages got - alleviating the global warming. The price of compostable plastics will be competitive as the crude oil price goes up and with large scale production. The survey finding suggests that the general public support the use of compostable plastics and see the goods brought by them and concluded that this waste management project should be implemented in other areas. The program organisers also suggest that there should be legislation tools to help in the application. Good communication with the manufacturers and the customers is important in commercialising BPs, so that they both realise the importance and advantages of using them.

From the result of this program, it is very important to get the support from the public to a new policy. The public has to be informed for the purpose of the policy and the advantages brought by it. In this case, the public support the introduction of BPs because BPs are believed to be environmentally friendly. It is obvious that this is largely depends on the civil education to and awareness of the general public towards the environmental issues. In the Kassel Project, it does not reveal where the compost would be used. Is it feasible to be used within the city? We don't know if there is a market to digest the compost or if the market is large enough. This is very important because if there is no or small market for the compost, there will be an accumulation of the compost. The compost can be sold to another cities or countries, but it may not be economically viable which hinders the support from the public to a policy.

\section{Obstacles to biodegradable plastics}

The general public is now more demanding to the environmentally friendly products, but the market share of BPs is still small when compare to the conventional plastics. The market of BPs is limited by the resources availability, cost of production and the political and legal atmosphere (EB, 2008).

\subsection{Resources availability}

Some of the feedstock for BPs is renewable and extracted from the crops, there is a conflict between the food availability and the sources of the renewable resources for producing BPs. The rising human population will worsen the problem. The conflict of the same material for food and green resources is illustrated by the soaring corn price in recent years because it is used to produce ethanol as a cleaner fuel and causes the increase in price of all corn related food (Jagger and Mortished, 2007); however, it is claimed that there is potential to increase the crops growing capacity and conflicts can be avoided (EB, 2008; Stevens, 2002). Research is conducting to broadening the sources to make BPs from food wastes (EB, 2008; Stevens, 2002).

\subsection{High price of biodegradable plastics}

The biggest obstacle of the BPs facing is the high production cost (compared with the conventional, petroleum-based polymers), which limit their commercial market and, hence, the future development. The price of BPs is higher than the conventional plastics and this hampers their development and commercialisation (Lee et al., 2003; Verlinden et al., 2007; Zheng et al., 2005). The conventional plastics have been emerged since half a century ago. There are infrastructures for their manufacturing. Comparing with the BPs, they are relatively new and the development is not yet mature enough to have a large market, and actually most of them are still in the experimental stage. As they are more expensive, they are limited in the use in the medical field. Price will go lower if there is a large market; but if the price does not drop, it is difficult to expand the market - it is a vicious circle. Some BPs production was halted because of the production cost is not competitive with the conventional plastics (Darby, 2012; Slater et al., 2003); although some raw materials for making the BPs are actually relatively cheaper than making conventional plastics: sugar costs 200-250 EUR per tone compare with 400-600 EUR per tone for ethylene/propylene (IBAW, 2005a). The price of PHA is high because of the cost of carbon substrate; the production of PHA can be lowered by employing inexpensive or less costly carbon substrates (Lee, 1996b). The time and cost consuming identification of correct strain for production also contribute to the high price of PHA. Price of BPs is still expected to be higher than the conventional plastics, given that there are fewer infrastructures for large-scale manufacturing. BPs price dropped in the past decade implies that the price is able to continue to drop when the technology becomes mature (EB, 2008). ICI started researches on BPs in 1970s as the oil price increased. It would not be surprising when the petroleum price keeps rising to the point that the cost of producing BPs is more favourable, or some uncertainties, like, the oil crisis in 1973, favour the development of BPs (Mecking, 2004). If the price for the solid waste collection, if any, increases, BPs would be more favourable too (Darby, 2012). Ren (2003) suggested that the lower cost of running composting plants may favour and compensate the use of less economical competitive BPs.

\subsection{Lack of infrastructures}

As BPs are relatively new technology, there is less infrastructure for its manufacture compare to the conventional one, although it may be because it does not have a large share in the market. Even if we can produce an economically viable 
BPs, there is currently not enough after-use treatments infrastructure. There are only a small number of countries which employing composting. This somehow discourages the use of BPs in other countries. In addition to the composting plant, it is not possible to encourage home composting in the dense living areas. As mentioned before, there is a need to have a flawless post-use system for the BPs. There is a lack of suitable waste management system, such as, the sorting system and composting facilities. This is another reason which hinders the commercialisation of BPs (Zheng et al., 2005) and can be improved by appropriate legislations and policies.

\section{Biodegradability of plastics concept}

\subsection{Degradability of plastics}

While BPs can help in waste management, there has been criticism that BPs are not so "green" (environmentally friendly). Voices are heard that the use of renewable materials does not equal to environmentally friendly or sustainable (Scott, 2003; Slater et al., 2003). To assess how environmentally friendly a product or service is, the whole production cycle is checked, called life cycle assessment. Opponents suggest that BPs used fossil fuels even they are made from renewable materials (Mecking, 2004). When the life cycle assessment is checked, the transport and energy used in the production cycle involve the consumption of the fossil fuels. As mentioned in the above sections, the conflicts between using the same sources for food and green materials can be solved by occupying the vacant potential agricultural lands. However, over half of it is in developing countries (EB, 2008) which will increase the fuel use in transportation if that is the plan. However, if the energy and fuel sources can switch to renewable sources, it would be greener. Opponents also suggest that the composting is not environmental friendly in term of the carbon dioxide emission (Mecking, 2004). Composting produces as much carbon dioxide as incineration, while incineration may be more encouraging as it can also produce energy. Waste disposal to landfill does not produce carbon dioxide at all, methane produced is a potential source of energy (Gross et al., 1995; Gu et al., 1993a).

\subsection{Degradation of plasticizers}

The increasing consumption and usage of plastics products have result in accumulation of wastes after consumption, especially in light of the structural polymeric materials and packaging (Gu, 2017, 2020, 2021). Landfill has been the common route for these plastics wastes to be disposed of, and high concentration of plasticizers has been found leaching from the wastes. A large array of chemicals are used as additives in the manufacturing of plastics products and such plasticizer is not bound covalently to the plastic resin and is therefore susceptible to migrate into the environment (Gu, 2017). In addition, plasticizers are also widely used in from structural and sport materials, home furnishings, transportation, clothing, and also in food and medical products (Gu et al., 1996a, 1996b, 1997, 1998, 2005). Due to the global utilization of them at large quantities, phthalate esters as an example have been detected in almost all environments in which they have been analyzed (Gu et al., 2000a, 2000b; Gu, 2017). Some of phthalate acid, phthalate esters and the degradation intermediates are suspected to cause cancer and kidney damage and, as a result, the US Environmental Protection Agency has added this class of chemicals to the list of priority pollutants recently.

Degradation of ortho-methyl phthalate ester (DMPE) was investigated using activated sludge and mangrove sediment for enrichment culture of aerobic bacteria. Morphologically distinctive microorganisms have been isolated and identified, and tested for the capability of degrading $o$-DMPE (Wang et al., 2003a, b). Comamonas acidovorans strain Fy-1 showed highest ability to degrade high concentrations of phthalate (PA) as high as 2,600 mg/l within 2 days (Wang et al., 2003a, b). Surprisingly, none of the bacteria from the enrichment culture is capable of degrading $o$-DMPE. When the isolates were reconstituted into consortia of culture, two consortia of microorganisms, one comprising of Pseudomonas fluorescens, Pseudomonas aureofacien and Sphingomonas paucimobilis, and the other of Xanthomonas maltophilia and Sphingomonas paucimobilis, showed capability in completely degradation of $o$-DMPE in 2 to 4 days (Wang et al., 2003b). The three species consortium appeared to be more effective in degradation of $o$-DMPE and both consortia proceeded through formation of mono-methyl phthalate (MMP) and then PA before mineralization (Figure 3). Degradation of $o$-DMPE has also been observed using bacteria enriched from mangrove and deep-ocean sediment, in all cases the degradation of $o$-DMPE requires at least two different micoorganisms to achieve the complete degradation of the chemical. In addition, degradation of dimethyl isophthalate also requires at least two microorganisms and the biochemical degradative pathway involves the two bacteria at different stage of hydrolysis of the substrate (Wang et al., 2003a, b, 2004). Furthermore, the active degradative culture has also been immobilized on surfaces of membrane fibers and high activity of the microorganisms was detected, further indicating the feasibility of utilizing the bacterial consortium in mineralizing $o$-DMPE. It is possible that high concentrations of endocrine-disrupting chemicals PA and DMPE can be mineralized in wastewater treatment system by indigenous microorganisms. Similarly, di- $n$-butyl phthalate can be degraded by Pseudomonas fluorescens (Xu et al., 2005a, b).

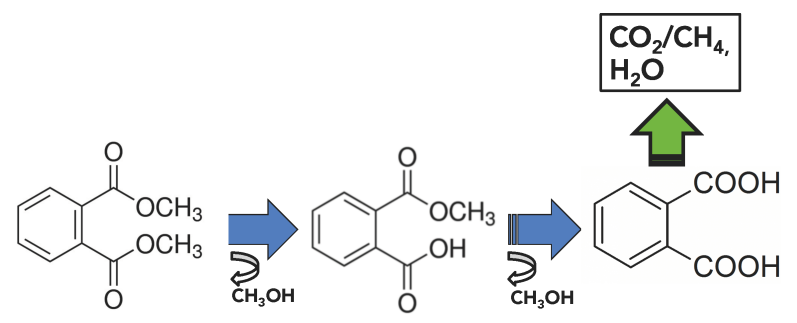

Figure 3. A proposed biochemical metabolic pathway for the degradation of ortho-dimethyl phthalate (DMP), a plasticizer, by microorganisms from natural environment 
Degradation of selective phthalate esters may require the cooperation of different microorganisms to achieve the fully mineralization of the plasticizers ( $\mathrm{Li}$ and Gu, 2006a, b, 2007; Li et al., 2005a, 2005b). In addition, fungi of mangrove are also capable of degrading these common plasticizers (Luo et al., 2009, 2011, 2012)

\section{Assessment of Current Status}

In order to smooth the commercialisation of BPs, there should be a good communication between the manufacturers, compost users and the public. It is not easy to persuade the producers to switch to use a more expensive feedstock; users of the end-product - compost - should be confident to the compost so that the market can be built up and the price of compost should be competitive; the public has to be informed for the merits of using BPs.

The price of BPs is the biggest barrier for its commercialization, so it has to be lowered to expand its share in the market. PHA price is determined by PHA yield from one carbon substrate, price of manufacturing requirements, recovery method and PHA content. By using cheaper carbon substrates, the production cost can also be lowered. If glucose is replaced by corn starch, the production cost of $\mathrm{P}(3 \mathrm{HB})$ can be decreased by about US\$1 per $\mathrm{kg}$ (Choi and Lee, 1999). Lee et al. (Lee et al., 2003) suggests that the production cost of PHB can be lowered by $20 \%$ by using cheaper carbon substrate. PHB can also be produced by using organic wastes (Haas et al., 2008), so the cost of production is believed to be lower. Suitable bacteria should be identified to be able to grow fast feeding on the cheaper substrates and produce high PHA content. However, the PHA yield from cheap carbon substrates is not satisfactory (Choi and Lee, 1999). To attain a certain property for the polymer, co-polymer is produced by the addition of co-substrates. Co-substrates increase the production cost of PHA as most of the co-substrates are expensive and hinder the growth of the bacteria (Choi and Lee, 1999). Oxygen is supplied for the growth for the bacteria. It is a costly inventory because oxygen has to be supplied equally to every corner in the incubator by mixing, in a rate that can maintain the growth rate (Choi and Lee, 1999) and ensure the safety in the factory with loads of oxygen. Lee et al. (Lee et al., 2003) also suggests that different recovery methods can result in different production cost. Extraction by aqueous solution is less expensive, but the polymers obtained are less favourable (Luzier, 1992). The PHA content is important in determining the cost of producing PHA as it affects the size of incubator (the cost of it and also the space occupied by it) used and the cost of recovery methods (Choi and Lee, 1999). Cost of PHA production is cheaper for large scale production because it is labour intensive for small scale production. Cheaper PHA production can be obtained by genetically modified plant (Ojumu et al., 2004). It is a controversial issue of whether the cost of BPs should be reduced by the genetically modified organisms (plants or bacteria) or not. If precaution step for disturbing the ecosystem is taken, it should not be a big problem and the public concern can be relieved; although it will not be an easy task. More research is needed on searching for the less expensive carbon substrates, methods of efficient polymer yield and recovery to produce cheaper BPs and make them popularize.

In order to advocate the development of BPs, it should be environmentally friendly and economically viable. As stated in Section 7, the BPs may not be as "green" as we thought before. It is believed that with more research to be done in the future on developing more environmentally friendly energy generating methods, the production of BPs will be more environmentally acceptable. It is suggested that the life cycle assessment should also take the post-use treatment of plastics into consideration, so that a true "cradle to grave" assessment is obtained rather than only focusing on the production process (Patel, 2003).

To make BPs successful in solving the waste management problem, BPs must have a bigger share in the market. To promote the commercialization of BPs, undoubtedly, the price of BPs should go down which can be done by more research, education and economic incentive. Education is needed to promote the benefits of using BPs. Well cooperated policies and legislations are also essential to facilitate the use of BPs. Economic instruments are very powerful tools to change people's behaviour if they are planned and implemented effectively (Ren, 2003). Economic incentive provided by the government is suggested for any new policy implementation (Boyle, 2000). It usually tries to fill the price gap between the conventional products with the greener products to attract more application. Economic incentive should be provided when necessary as the price of biodegradable materials is currently higher than the conventional plastics. It can be in the form of lower tax rate for BPs, increase landfill tax or grant or loans for the development of BPs.

Despite the promotion of the use of BPs, a holistic waste management policy is required for this new product. A series of flawless after-use treatment facilities should be instated. Separation of BPs waste with other non-compostable waste is important to the quality of the compost produced. A good sorting system should be established. It can be done at source (at the generation stage - household) or right before goes into the composting process, however, the cost is high (Ren, 2003). The screening of contaminants is difficult and leads to the failure of implementation of composting. If separation at source is employed, again, it should be accompanied with education, promotion and economic incentives. The source separation of plastics, metals and paper waste in Hong Kong is carried out in a voluntary basis, there is only $40 \%$ of the interviewees have done the waste separation in a recent survey. More than $60 \%$ of the interviewees thinks that the sorting of waste is troublesome and do not have time to do, but suggested that they will be more willing to do it if there is economic incentives (WWP et al., 2009). UNEP (2009) also admits that the separation at source is currently not feasible because the economic and environmental incentives are weak. The public should be explained for the waste management problem that is facing, how BPs can help and be informed for how the conventional plastics will spoil the compost quality. Effective waste management methods cannot be obtained without 
proper education to the public (Boyle, 2000). It is illustrated by the Kassel Project that education campaigns should be carried out at the beginning of the implementation stage to raise the public awareness and educate the public for the proper disposal methods. Regulations and good law enforcement are also helpful in regulating the waste goes into the landfills.

The market of the end-product - compost - may determine the commercialization of BPs. If there is limited market of compost, the compost left is another waste problem which has to be managed. Using the compost in the public sector or selling it to the nearby countries should be considered. If the compost is going to be sold, a labelling system can be set up. It can be similar to the logo system for compostable plastics as mentioned in Section 4.3. It can ensure the quality of compost and build up confidence among the consumers.

BPs can provide an alternative to the traditional waste management methods for plastics. Composting does not only avoid producing the carcinogenic dioxin (which will be produced by the incineration of plastics), but also divert BPs from landfilling (which will be overflowed and new site for landfills become scarce). However, BPs should not be viewed as the sole solution to lessen the burden of landfills. The advocate of BPs should not be viewed as "encouraging the use of disposable products", as it has been stated by the Hong Kong Special Administration Region Government during the release of local testing guideline for degradable products (EPD, 2000). There is a responsibility of the local government to explain to the public that BPs is a tool to help in the waste management in both the short and long term, but reducing waste generation is the ultimate goal of waste management. People will think that they can buy or use more biodegradable products and dumped randomly as they will eventually bioassimilated. Environmental awareness should be increased to change the behaviour of people. Plastics waste is not the only contributor for the overflow of landfills, lifestyle of the public should be changed to reduce the waste generation. Packaging which is not for hygienic reason should be reduced, this can be achieved by economic instruments (e.g., increasing solid waste disposal tax), education and related policies and legislations. As plastics are currently in the form of carrying bags, encouragement to the public for bringing their own bags is also help in reducing the waste produced.

\section{Conclusions and Future Perspec- tives}

Petroleum-based plastics are part of our daily life but service life of packaging is usually short. Petrol-chemical plastics are resistant to degradation and will stay in the environment for a long time. Large volume generated and long time required for degradation lead to accumulation of plastics to undesirable environmental issues, such as ingestion by marine animals, deteriorating the soil quality for crop growth, and waste management problem. Fundamental change in consumption life style needs to be changed with least usage of plastics as packaging to significantly decrease the impact of plastics to the environment. Biodegradation of plastics depends on the environmental conditions and, more importantly, the establishment of active microorganisms. Biodegradation of conventional plastics can be carried out decades in the soil, but both abiotic and biological processes are involved to contribute to the degradation observed.

Compostable plastics require separate treatment through sorting of waste collection. This has to be accompanied by an effective waste collection and management system. In addition, educating the general public about the advantages of BPs and providing economic incentives for purchasing BPs can promote the use of BPs. These can be achieved by appropriate legislations and policies. Application of BPs should not be viewed as an encouragement of dispose more, in contrast, it should be viewed as a long term waste management tools to solve the landfilling problem. The ultimate goal is to reduce the waste generated, so education to the public not to use more than they need is essential.

Research on petroleum-based plastics shall take into account of the chemistry of the plastics materials, product formulation, the environmental conditions of assessment and the mechanisms involved for the degradation and transformation of the polymeric materials to low molecular weight products and substantial mineralization. The microorganisms shall be evaluated for the biochemical processes in degradation of the neat plastic resin than commercial products. Degradability of plastics is basically easy in experimental design and planning, but a substantial degradation of them can be very timeconsuming because of the very slow degradation rate initial by microorganisms. In particular, there is no good evidence on the initial attacks of polymeric materials by biochemical reaction and the gene involved in the literature available. On a scientific ground, degradation tests of plastics and polymeric materials must follow the necessary guidelines and requirements, so that the results obtained are sound and valid on a solid ground. With a better knowledge on the current pitfalls on this research topic, future research on this research can avoid the shortcomings to gain further in-depth knowledge to advance the science on this subject to a significant extent.

\section{Acknowledgements}

Research in my laboratory has been supported by research grants from National Natural Science Foundation of China.

\section{References}

Agamuthu, P. and Faizura P.N., 2005. Biodegradability of degradable plastic waste. Waste Management \& Research, 23 (2): 95-100. https://doi.org/10.1177/0734242X05051045

Agarwala, S.P., 2006. Environmental studies. Oxford, UK, 220 p.

Ahmed, T., M. Shahid, F. Azeem, I. Rasul, A.A. Shah, M. Noman, A. Hameed, N. Manzoor, I. Manzoor, and S. Huhammad, 2018. Biodegradation of plastics: current scenario and future prospects for environmental safety. Environmental Science and Pollution Research, 25(1): 1-12.

https://doi.org/10.1007/s11356-018-1234-9 
Albertsson, A.-C., 1980. The shape of the biodegradation curve for low and high density polyethylenes in prolonged series of experiments. European Polymer Journal, 16(7): 623-630. https://doi.org/10.1016/0014-3057(80)90100-7

Albertsson, A.-C., Barenstedt, C. and Karlsson, S., 1994. Abiotic degradation products from enhanced environmentally degradation polyethylene. Acta Polymerica, 45(2): 97-103. https://doi.org/10.1002/actp.1994.010450207

Amaral-Zettler, L.A., E.R. Zettler, and T.J. Miner, 2020. Ecology of the plasticsphere. Nature Reviews Microbiology, 18: 139-151. https://doi.org/10.1038/s41579-019-0308-0

Anon, 1975. Plastic cups found in fish. Marine Pollution Bulletin, 6(10): 148 https://doi.org/10.1016/0025-326X(75)90178-2

Baird, R.W. and Hooker, S.K., 2000. Ingestion of plastic and unusual prey by a juvenile harbour porpoise. Marine Pollution Bulletin, 40(8): 719-720.

https://doi.org/10.1016/S0025-326X(00)00051-5

BBC News, 2005. Kenyan chain drops plastic bags. BBC News. Updated on 13th July 2005.

BBC News, 2007. Town pledges to bin plastic bags. BBC News. Updated on 17th July 2007.

BBC News, 2008. Kew Gardens to ban plastic bags. BBC News. Updated on 28th June 2008.

Birnbaum, L.S. and Fenton, S.E., 2003. Cancer and developmental exposure to endocrine disruptors. Environmental Health Perspectives, 111(4): 389-394. https://doi.org/10.1289/ehp.5686

Bonhomme, S., Cuer, A., Delort, A-M., Lemaire, J., Sancelme, M., Scott, G., 2003. Environmental biodegradation of polyethylene. Polymer Degradation and Stability, 81(3): 441-452. https://doi.org/10.1016/S0141-3910(03)00129-0

Boyle, C.A., 2000. Solid waste management in New Zealand. Waste Management, 20(7): 517-526. https://doi.org/10.1016/S0956-053X(00)00023-4

Bugoni, L, Krause, L. and Petry, M.V., 2001. Marine debris and human impacts on sea turtles in southern Brazil. Marine Pollution Bulletin, 42(12): 1330-1334.

https://doi.org/10.1016/S0025-326X(01)00147-3

Carpenter, E.J., Anderson, S.J., Harvey, G.R., Miklas, H.P., Peck, B.B., 1972. Polystyrene spherules in coastal waters. Science, 178(4062): 749-750

https://doi.org/10.1126/science.178.4062.749

Carpenter, E.J. and Smith, K.L. Jr., 1972. Plastics on the Sargasso Sea surface. Science, 175(4027): 1240-1241. https://doi.org/10.1126/science.175.4027.1240

CEN, European Committee for Standardization, 2009. About us. http://www.cen.eu/cenorm/aboutus/index.asp

Chen, G.Q., 2003. Production and applications of microbial polyhydroxyalkanoates. In: Biodegradable Polymers and Plastics (eds: Chiellini, E. and Solaro, R.). Kluwer Academic/Plenum Publishers, New York, USA, pp 155-166.

https://doi.org/10.1007/978-1-4419-9240-6_11

Cheung, J.K.H., R.K.W. Lam, M.Y. Shi, J.-D. Gu, 2007. Environmental fate of the endocrine disruptors, dimethyl phthalate esters (DMPE), under anoxic sulfate-reducing conditions. Science of the Total Environment, 381: 126-133.

https://doi.org/10.1016/j.scitotenv.2007.03.030
Chiellini, E., Chiellini, F., Cinelli, P., Ivanova, V., 2003. Biobased polymeric materials for agriculture applications. In: Biodegradable Polymers and Plastics (eds: Chiellini E. and Solaro R.). Kluwer Academic/ Plenum Publishers, New York, USA, pp 185210

https://doi.org/10.1007/978-1-4419-9240-6_13

Choi J. and Lee S.Y., 1999. Factors affecting the economics of polyhydroxyalkanoate production by bacterial fermentation. Applied Microbiology and Biotechnology, 51(1): 13-21. https://doi.org/10.1007/s002530051357

Connors P.G. and Smith K.G., 1982. Oceanic plastic particle pollution: suspected effect on fat deposition in red phalaropes. Marine Pollution Bulletin, 13(1): 18-20. https://doi.org/10.1016/0025-326X(82)90490-8

Cox M.K., 1995. Recycling BIOPOL - composting and material recycling. In: Degradable Polymers, Recycling, and Plastics Waste Management. (eds: Albertsson A-C., Huang S.J.). New York: M. Dekker, pp 15-20. https://doi.org/10.1080/10601329508010274

Danso, D., J. Chow, and W.R. Streit, 2019. Plastics: environmental and biotechnological perspectives on microbial degradation. Applied and Environmental Microbiology, 85: e01095-19. https://doi.org/10.1128/AEM.01095-19

Darby, D., 2012. Compostable plastics and environmental marketing claims. Biocycle, 53(10): 53.

http://www.biocycle.net/compostable-plastics-andenvironmental-marketing-claims/

Degli, Innocenti, F., 2003. Biodegradability and compostability. In: Biodegradable Polymers and Plastics (eds: Chiellini E. and Solaro R.). Kluwer Academic/ Plenum Publishers, New York, USA, pp 33-45. https://doi.org/10.1007/978-1-4419-9240-6_2

Derraik, J.G.B., 2002. The pollution of the marine environment by plastic debris: a review. Marine Pollution Bulletin, 44(9): 842852. https://doi.org/10.1016/S0025-326X(02)00220-5

EB, European Bioplastics, 2008. Bioplastics: frequently asked questions (FAQs). http://www.european-bioplastics.org/index.php?id=191

EB, European Bioplastics, 2009a. Certification of compostable bioplastic products. http://www.european-bioplastics.org/index.php?id=156

EB, European Bioplastics, 2009b. Certification Details. http://www.european-bioplastics.org/index.php?id=157

Freier, T., Sternberg, K., Behrend, D., Schmitz, K-P., 2003. Health issues of biopolymers: polyhydroxybutyrate. In: Biopolymers (Volume 10) General Aspects and Special Applications (eds: Steinbüchel A.). Wiley-VCH, Weinheim, Germany, pp 247-280. https://doi.org/10.1002/3527600035.bpola008

EPD, Environmental Protection Department (2000) EPD launches testing guideline for degradable products.

http://www.epd.gov.hk/epd/english/news_events/press/press_00122 9a.html

EPD, Environmental Protection Department (2006) Waste Reduction Framework Plan.

https://www.epd.gov.hk/epd/mobile/sc_chi/environmentinhk/waste /waste_maincontent.html

Ghatge, S., Yang, Y., Ahn, J.-H., Hur, H.-G., 2020. Biodegradation of polyethylene: a brief review. Applied Biology and Biochemistry, 63: 27.

https://doi.org/10.1186/s13765-020-00511-3 
Gramentz, D., 1988. Involvement of loggerhead turtle with the plastic, metal, and hydrocarbon pollution in the central Mediterranean. Marine Pollution Bulletin, 19(1): 11-13. https://doi.org/10.1016/0025-326X(88)90746-1

Greene, J., 2007. Biodegradation of compostable plastics in green yard-waste compost environment. Journal of Polymers and the Environment, 15(4): 269-273. https://doi.org/10.1007/s10924-007-0068-1

Gross, R.A. and Kalra, B., 2002. Biodegradable polymers for the environment. Science, 297(5582): 803-807. https://doi.org/10.1126/science.297.5582.803

Gross, R.A., J.-D. Gu, D. Eberiel, S.P. McCarthy, 1995. Laboratory scale composting test methods to determine polymer biodegradability: model studies on cellulose acetate. Journal of Macromolecule Science - Pure \& Applied Chemistry, A32: 613-628. https://doi.org/10.1080/10601329508010275

$\mathrm{Gu}$, J.-D., 1999. Microbial corrosion of metals and deterioration of polymeric materials. Journal of Materials Engineering, 7, 4-8. (in Chinese)

Gu, J.-D., 2003a. Microbiological deterioration and degradation of synthetic polymeric materials: recent research advances. International Biodeterioration and Biodegradation, 52(2): 69-91. https://doi.org/10.1016/S0964-8305(02)00177-4

Gu, J.-D., 2003b. Microbial deterioration of synthetic and biological polymers used in engineering and construction. Pages 97-138. In: A. Steinbüchel (ed.), Biopolymers. Vol. 10: Special Applications and General Aspects. Wiley-VCH Verlag GmbH, Weinheim, Germany. https://doi.org/10.1002/3527600035.bpola003

Gu, J.-D., 2012. Chapter 8: Biofouling and prevention: corrosion, biodeterioration and biodegradation of materials. Pages 243-282. In: M. Kultz, (ed.), Handbook of Environmental Degradation of Materials ( ${ }^{2 n d}$ ed.). Elsevier, Waltham, Massachusetts. https://doi.org/10.1016/B978-1-4377-3455-3.00008-0

Gu, J.-D., 2017. Biodegradability of plastics: the pitfalls. Applied Environmental Biotechnology, 2(1): 58-60. https://doi.org/10.26789/AEB.2017.01.008

Gu, J.-D., 2018. The endocrine-disrupting plasticizers will stay with us for a long time. Applied Environmental Biotechnology, 3(1): 61-64. http://doi.org/10.26789/AEB.2018.01.008

Gu, J.-D., 2020. Anthroposphere, a new physical dimension of the ecosystems. Applied Environmental Biotechnology, 5(1): 1-3. http://doi.org/10.26789/AEB.2020.01.001

Gu, J.-D., 2021. Biodegradability of plastics: the issues, recent advances and future perspectives. Environmental Science and Pollution Research 28(2): 1278-1282. https://doi.org/10.1007/s11356-020-11501-9

Gu, J.-G. and J.-D. Gu (2005. Methods currently used in testing microbiological degradation and deterioration of a wide range of polymeric materials with various degree of degradability: a review. Journal of Polymers and the Environment, 13: 65-74. https://doi.org/10.1007/s10924-004-1230-7

Gu, J.-D. and R. Mitchell, 2013. Biodeterioration. In: E. Rosenberg, E.F. DeLong, S. Lory, E. Stackebrandt, and F. Thompson, (Eds), Pages 309-341. The Prokaryotes: Applied Bacteriology and Biotechnology. Springer-Verlag, New York. https://doi.org/10.1007/978-3-642-31331-8_31

Gu, J.-D. and Y. Wang, 2013. Microbial transformation of phthalate esters: diversity of hydrolytic esterases. Pages 313-345. In:
M.H. Wong, (ed.), Environmental Contamination - Health Risks, Bioavailability and Bioremediation. CRC Press, Boca Raton, Florida.

Gu, J.-D., D.T. Eberiel, S.P. McCarthy, and R.A. Gross, 1993a. Cellulose acetate biodegradability upon exposure to simulated aerobic composting and anaerobic bioreactor environments. Journal of Environmental Polymer Degradation, 1: 143-153. https://doi.org/10.1007/BF01418207

Gu, J.-D., D. Eberiel, S.P. McCarthy, and R.A. Gross, 1993b. Degradation and mineralization of cellulose acetate in simulated thermophilic compost environments. Journal of Environmental Polymer Degradation, 1: 281-291. https://doi.org/10.1007/BF01458295

Gu, J.-D., S. Coulter, D. Eberiel, S.P. McCarthy, and R.A. Gross, 1993c. A respirometric method to measure mineralization of polymeric materials in a matured compost environment. Journal of Environmental Polymer Degradation, 1: 293-299.

https://doi.org/10.1007/BF01458296

Gu, J.-D., S. Yang, R. Welton, D. Eberiel, S.P. McCarthy, and R.A. Gross, 1994. Effects of environmental parameters on degradability of polymer films. Journal of Environmental Polymer Degradation, 2: $129-135$ https://doi.org/10.1007/BF02074781

Gu, J.-D., T. Ford, K. Thorp, and R. Mitchell, 1996a. Microbial growth on fiber reinforced composite materials. International Biodeterioration \& Biodegradation, 37: 197-203. https://doi.org/10.1016/S0964-8305(96)00035-2

Gu, J.-D., T. Ford, and R. Mitchell, 1996b. Susceptibility of electronic insulation polyimides to microbial degradation. Journal of Applied Polymer Science, 62: 1029-1034.

Gu, J.-D., C. Lu, K. Thorp, A. Crasto, and R. Mitchell, 1997. Fiberreinforced polymeric composite are susceptible to microbial degradation. Journal of Industrial Microbiology and Biotechnology, 18: 364-369. https://doi.org/10.1038/sj.jim.2900401

Gu, J.-D., M. Roman, T. Esselman, and R. Mitchell, 1998. The role of microbial biofilms in deterioration of space station candidate materials. International Biodeterioration \& Biodegradation, 41: 25-33. https://doi.org/10.1016/S0964-8305(97)00070-X

Gu, J.-D., Ford, T.E., Mitchell, R., 2000a. Microbial degradation of materials: general processes. In: Uhlig's Corrosion Handbook. (ed: Revie R.W.). New York: John Wiley \& Sons, pp 349-365.

Gu, J.-D., Ford, T.E., Mitton, D.B., Mitchell R., 2000b. Microbiological degradation of polymeric materials. In: Uhlig's Corrosion Handbook. (ed: Revie R.W.). New York: John Wiley \& Sons, pp 439-460.

Gu, J.-D., J. Li, and Y. Wang, 2005. Biochemical pathway and degradation of phthalate ester isomers by bacteria. Water Science and Technology, 52(8): 241-248. https://doi.org/10.2166/wst.2005.0269

Haas, R., Jin, B., Zepf, F.T., 2008. Production of poly(3hydroxybutyrate) from waste potato starch. Bioscience, Biotechnology, and Biochemistry, 72(1): 253-256. https://doi.org/10.1271/bbb.70503

Huang, J.C., Shetty, A.S., Wang, M.S., 1990. Biodegradable plastics: a review. Advances in Polymer Technology, 10(1): 23-30. https://doi.org/10.1002/adv.1990.060100103

Huang, S.J., 1995. Polymer waste management - biodegradation, incineration, and recycling. In: Degradable Polymers, Recycling, 
and Plastics Waste Management. (eds: Albertsson A-C., Huang S.J.). New York: M. Dekker, pp 1-5.

https://doi.org/10.1080/10601329508010272

IBAW, Interessegemeinschaft Biologisch Abbaubare Werkstoffe, 2005a. Highlights in bioplastics.

IBAW, Interessegemeinschaft Biologisch Abbaubare Werkstoffe, 2005b. Recommendation on the implementation of compostable packaging.

Ishigaki, T., Sugano, W., Nakanishi, A., Tateda, M., Ike, M., Fujita, M., 2004.)The degradability of biodegradable plastics in aerobic and anaerobic waste landfill model reactors. Chemosphere, 54(3): 225-233.

https://doi.org/10.1016/S0045-6535(03)00750-1

Jagger, S. and Mortished, C., 2007. Ice-cream makers frozen out as corn price rises. Times Online. England.

http://business.timesonline.co.uk/tol/business/markets/united states/article2080599.ece

Jakubowicz, I., 2003. Evaluation of degradability of biodegradable polyethylene (PE). Polymer Degradation and Stability, 80(1): 3943. https://doi.org/10.1016/S0141-3910(02)00380-4

Jayasekara, R., Harding, I., Bowater, I., Lonergan G., 2005. Biodegradability of a selected range of polymers and polymer blends and standard methods for assessment of biodegradation. Journal of Polymers and the Environment, 13(3): 231-251. https://doi.org/10.1007/s10924-005-4758-2

JBPA, Japan BioPlastics Association, 2007. Standards for compostable GreenPla products. http://www.jbpaweb.net/english/g-5.pdf

Jones, M.M., 1995. Fishing debris in the Australian marine environment. Marine Pollution Bulletin 30, 1): 25-33. https://doi.org/10.1016/0025-326X(94)00108-L

Kathiresan, K., 2003. Polythene and plastics-degrading microbes from the mangrove soil. Revista de Biologia Tropical, 51, 3-4): 629-633.

Koller, M., Bona, R., Chiellini, E., Fernandes, E.G., Horvat, P., Kutschera, C., Hesse, P., Braunegg, G., 2008. Polyhydroxyalkanoate production from whey by Pseudomonas hydrogenovora. Bioresource Technology, 99, 11): 4854-4863. https://doi.org/10.1016/j.biortech.2007.09.049

Körner, I., Redemann, K. and Stegmann, R., 2005. Behaviour of biodegradable plastics in composting facilities. Waste Management 25(4): 409-415.

https://doi.org/10.1016/j.wasman.2005.02.017

Kumar, M.S., Mudliar, S.N., Reddy, K.M.K., Chakrabarti, T., 2004. Production of biodegradable plastics from activated sludge generated from a food processing industrial waste water treatment plant. Bioresource Technology, 95(3): 327-330. https://doi.org/10.1016/j.biortech.2004.02.019

Kyrikou, I. and Briassoulis, D., 2007. Biodegradation of agricultural plastic films: a critical review. Journal of Polymers and the Environment, 15(2): 125-150.

https://doi.org/10.1007/s10924-007-0053-8

Laist, D.W., 1987. Overview of the biological effects of lost and discarded plastic debris in the marine environment. Marine Pollution Bulletin 18(6B): 319-326. https://doi.org/10.1016/S0025-326X(87)80019-X

Lane, M., 2003. Why can't we recycle all this plastic? BBC News Online. Updated on 19th September 2003.
LCSD, Leisure and Cultural Services Department, 2005. Green School Handbook.

http://www.lcsd.gov.hk/green/en/organic.php

Lee, S.Y., 1996a. Bacterial polyhydroxyalkanoates. Biotechnology and Bioengineering, 49(1): 1-14. https://doi.org/10.1002/(SICI)1097-0290(19960105)49:1<1:: AID-BIT1 > 3.0.CO;2-P

Lee, S.Y., 1996b. Plastic bacteria? Progress and prospects for polyhydroxyalkanoate production in bacteria. Trends in Biotechnology, 14(11): 431-438. https://doi.org/10.1016/0167-7799(96)10061-5

Lee, S.Y., Park, S.J., Park, J.P., Lee, Y., Lee, S.H., 2003. Economic aspects of biopolymer production. In: Biopolymers(Volume 10) General Aspects and Special Applications(eds: Steinb ̈̈chel A.) Wiley-VCH, Weinheim, Germany, pp 307-338. https://doi.org/10.1002/3527600035.bpola010

Li, J., and J.-D. Gu, 2006a. Biodegradation of dimethyl terephthalate by Pasteurella multocida Sa follows an alternative biochemical pathway. Ecotoxicology, 15: 391-397. https://doi.org/10.1007/s10646-006-0070-8

Li, J., and J.-D. Gu, 2006b. Biochemical cooperation between Klebsiella oxytoca Sc and Methylobacterium mesophilium Sr for complete degradation of dimethyl isophthalate. Water, Air and Soil Pollution, 6: 569-574. https://doi.org/10.1007/s11267-006-9041-6

Li, J., and J.-D. Gu, 2007. Complete degradation of dimethyl isophthalate requires the biochemical cooperation between Klebsiella oxytoca Sc and Methylobacterium mesophilicum Sr isolated from wetland sediment. Science of the Total Environment, 380: 181187.

https://doi.org/10.1016/j.scitotenv.2006.12.033

Li, J., J.-D. Gu, and L. Pan, 2005a. Transformation of dimethyl phthalate, dimethyl isophthalate and dimethyl terephthalate by Rhodococcus rubber $\mathrm{Sa}$ and modeling the processes using the modified Gompertz model. International Biodeterioration \& Biodegradation, 55: 223-232. https://doi.org/10.1016/j.ibiod.2004.12.003

Li, J., J.-D. Gu, and J.-H. Yao, 2005b. Degradation of dimethyl terephthalate by Pasteurella multocida Sa and Sphingomonas paucimobilis Sy isolated from mangrove sediment. International Biodeterioration \& Biodegradation, 56: 158-165. https://doi.org/10.1016/j.ibiod.2005.07.001

Luo, Z.-H., K.-L. Pang, J.-D. Gu, R.K.K. Chow, and L.L.P. Virijmoed, 2009. Degradability of the three dimethyl phthalate isomer esters (DMPEs) by a Fusarium species isolated from mangrove sediment. Marine Pollution Bulletin. 58: 765-786. https://doi.org/10.1016/j.marpolbul.2009.03.005

Luo, Z.-H., Y.-R. Wu, K.-L. Pang, J.-D. Gu, and L.L.P. Vrijmoed, 2011. Comparison of initial hydrolysis of the three dimethyl phthalate ester (DMPEs) by a basidiomycetous yeast, Trichosporon DMI-5-1, from coastal sediment. Environmental Science and Pollution Research 18: 1653-1660. https://doi.org/10.1007/s11356-011-0525-1

Luo, Z.-H., Y.-R. Wu, R.K.K. Chow, J.-J. Luo, J.-D. Gu, and L.L.P. Vrijmoed, 2012. Purification and characterization of an intracellular esterase from a Fusarium species capable of degrading dimethyl terephthalate. Process Biochemistry, 47: 687-693. https://doi.org/10.1016/j.procbio.2012.01.015

Luzier, W.D., 1992. Materials derived from biomass/biodegradable materials. Proceedings of the National Academy of Sciences of 
the United States of America, 89(3): 839-842.

https://doi.org/10.1073/pnas.89.3.839

Mecking, S., 2004. Nature or petrochemistry? - biologically degradable materials. Angewandte Chemie International Edition, 43(9): 1078-1085.

https://doi.org/10.1002/anie.200301655

Miertus, S. and Ren, X., 2003. Environmentally degradable plastics and ICS-UNIDO global program. In: Biodegradable Polymers and Plastics (eds: Chiellini E. and Solaro R.). Kluwer Academic/ Plenum Publishers, New York, USA, pp 55-65. https://doi.org/10.1007/978-1-4419-9240-6_4

Mohee, R. and Unmar, G., 2007. Determining biodegradability of plastic materials under controlled and natural composting environments. Waste Management, 27(11): 1486-1493. https://doi.org/10.1016/j.wasman.2006.07.023

Mohee, R., Unmar, G.D., Mudhoo, A., Khadoo, P., 2007. Biodegradability of biodegradable/degradable plastic materials under aerobic and anaerobic conditions. Waste Management, 28(9): 16241629.

https://doi.org/10.1016/j.wasman.2007.07.003

Moser, M.L. and Lee, D.S., 1992. A fourteen-year survey of plastic ingestion by western north Atlantic seabirds. Colonial Waterbirds, 15(1): 83-94.

https://doi.org/10.2307/1521357

Mueller, R.J., 2006. Biological degradation of synthetic polyesters - enzymes as potential catalysts for polyester recycling. Process Biochemistry, 41(10): 2124-2128.

https://doi.org/10.1016/j.procbio.2006.05.018

Ojumu, T.V., Yu, J. and Solomon, B.O., 2004. Production of polyhydroyalkanoates, a bacterial biodegradable polymer. African Journal of Biotechnology, 3(1): 18-24.

https://doi.org/10.5897/AJB2004.000-2004

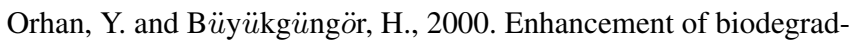
ability of disposable polyethylene in controlled biological soil. International Biodeterioration and Biodegradation 45(1-2): 4955. https://doi.org/10.1016/S0964-8305(00)00048-2

Otake, Y., Kobayashi, T., Asabe, H., Murakami, N., Ono, K., 1995. Biodegradation of low-density polyethylene, polystyrene, polyvinyl chloride, and urea formaldehyde resin buried under soil for over 32 years. Journal of Applied Polymer Science, 56(13): 1789-1796.

https://doi.org/10.1002/app.1995.070561309

Patel, M., 2003. Do biopolymers fulfill our expectations concerning environmental benefits? In: Biodegradable Polymers and Plastics (eds: Chiellini E. and Solaro R.). Kluwer Academic/ Plenum Publishers, New York, USA, pp 83-102. https://doi.org/10.1007/978-1-4419-9240-6_7

Quah, E. and Ong, Q., 2008. The greener the better? Not always. The Straits Times. 5th July 2008.

Ratajska, M. and Boryniec, S., 1999. Biodegradation of some natural polymers in blends with polyolefines. Polymers for Advanced Technologies, 10(10): 625-633.

https://doi.org/10.1002/(SICI)1099-1581(199910)10:10;625:: AID-PAT930;3.0.CO;2-X

Reddy, C.S.K., Ghai, R., Rashmi, Kalia V.C., 2003. Polyhydroxyalkanoates: an overview. Bioresource Technology, 87(2): 137-146. https://doi.org/10.1016/S0960-8524(02)00212-2

Ren, X., 2003. Biodegradable plastics: a solution or a challenge? Journal of Cleaner Production, 11(1): 27-40. https://doi.org/10.1016/S0959-6526(02)00020-3
Reske, J., 2003. Market introduction of compostable packaging. In: Biodegradable Polymers and Plastics (eds: Chiellini E. and Solaro R.). Kluwer Academic/ Plenum Publishers, New York, USA, pp 73-80. https://doi.org/10.1007/978-1-4419-9240-6_6

Restrepo-Florez, J., A. Bassi, and M. Thompson, 2014. Microbial degradation and deterioration of polyethylene - a review. International Biodeterioration \& Biodegradation, 88: 83-90. https://doi.org/10.1016/j.ibiod.2013.12.014

Rothstein, S.I.,, 1973. Plastic particle pollution of the surface of the Atlantic Ocean: evidence from a seabird. The Condor, 75(3): 344-345. https://doi.org/10.2307/1366176

Sartorius, I., 2003. Biodegradable plastics in the social and political environment. In: Biopolymers (Volume 10) General Aspects and Special Applications (eds: Steinb üchel A.). Wiley-VCH, Weinheim, Germany, pp 453-472.

https://doi.org/10.1002/3527600035.bpola015

Schroeter, J., 1998. Creating the framework for a widespread use of biodegradable polymers (standardization, labelling, legislation, biowaste management). Polymer Degradation and Stability, 59(13): $377-381$.

https://doi.org/10.1016/S0141-3910(97)00203-6

Scott, G., 1999. Polymers and the environment. Cambridge: Royal Society of Chemistry, United Kingdom, 132p.

Scott, G., 2000."Green” polymers. Polymer Degradation and Stability, 68(1): 1-7. https://doi.org/10.1016/S0141-3910(99)00182-2

Scott, G., 2003. Science and standards. In: Biodegradable Polymers and Plastics (eds: Chiellini E. and Solaro R.). Kluwer Academic/ Plenum Publishers, New York, USA, pp 3-32. https://doi.org/10.1007/978-1-4419-9240-6_1

Shah, A.A., Hasan, F., Hameed, A., Ahmed, S., 2008. Biological degradation of plastics: a comprehensive review. Biotechnology Advances, 26(3): 246-265. https://doi.org/10.1016/j.biotechadv.2007.12.005

Slater, S., Glassner, D., Vink, E., Gerngross, T., 2003. Evaluating the environmental impact of biopolymers. In: Biopolymers (Volume 10) General Aspects and Special Applications (eds: Steinb üchel A.). Wiley-VCH, Weinheim, Germany, pp 473-492. https://doi.org/10.1002/3527600035.bpola016

Stefatos, A., Charalampakis, M., Papatheodorou, G., Ferentinos, G., 1999. Marine debris on the seafloor of the Mediterranean Sea: examples from two enclosed gulfs in western Greece. Marine Pollution Bulletin 36(5): 389-393. https://doi.org/10.1016/S0025-326X(98)00141-6

Stevens, E.S., 2002. Green plastics: an introduction to the new science of biodegradable plastics. Oxford: Princeton University Press, Princeton, 238p. https://doi.org/10.1515/9780691214177

Stevens, E.S. and Goldstein N., 2002. How green are green plastics? BioCycle, 43(12): 42-45. https://doi.org/10.1016/S0034-3617(01)80145-4

Swift, G., 1995. Opportunities for environmentally degradable polymers. In: Degradable Polymers, Recycling, and Plastics Waste Management. (eds: Albertsson A-C., Huang S.J.). New York: M. Dekker, pp 49-59. https://doi.org/10.1080/10601329508010277

UNEP, United Nations Environment Programme, 2009. Newsletter and technical publications - municipal solid waste management. 
Verlinden, R.A.J., Hill, D.J., Kenward, M.A., Williams, C.D., Radecka, I., 2007. Bacterial synthesis of biodegradable polyhydroxyalkanoates. Journal of Applied Microbiology, 102(6): 14371449. https://doi.org/10.1111/j.1365-2672.2007.03335.x

Wang, Y., and J.-D. Gu, 2006a. Degradation of dimethyl isophthalate by Viarovorax paradoxus strain T4 isolated from deep-ocean sediment of the South China Sea. Journal of Human and Ecological Risk Assessment, 12: 236-247. https://doi.org/10.1080/10807030500531521

Wang, Y., and J.-D. Gu, 2006b. Degradation of dimethyl terephthalate by Variovorax paradoxus T4 and Sphingomonas paucimobilis DOS1 of the South China Sea. Ecotoxicology, 15: 549-557. https://doi.org/10.1007/s10646-006-0093-1

Wang, Y., B. Yin, Y.-G. Hong, Y. Yan, and J.-D. Gu, 2008. Degradation of dimethyl carboxylic phthalate ester by Burkholderia cepacia DA2 isolated from marine sediment of South China Sea. Ecotoxicology, 17: 845-852. https://doi.org/10.1007/s10646-008-0247-4

Wang, Y.Z., Yang, K.K., Wang, X.L., Zhou, Q., Zheng, C.Y., Chen, Z.F., 2004. Agricultural application and environmental degradation of photo-biodegradation polyethylene mulching films. Journal of Polymers and the Environment, 12(1): 7-10. https://doi.org/10.1023/B:JOOE.0000003122.71316.8e

Wang, Y., Y. Fan, and J.-D. Gu, 2003a. Microbial degradation of the endocrine-disrupting chemicals phthalic acid and dimethyl phthalate ester under aerobic conditions. Bulletin of Environmental Contamination and Toxicology, 71: 810-818. https://doi.org/10.1007/s00128-003-0207-x

Wang, Y., Y. Fan, and J.-D. Gu, 2003b. Aerobic degradation of phthalic acid by Comamonas acidovoran fy-1 and dimethyl phthalate ester by two reconstituted consortia from sewage sludge at high concentrations. World Journal of Microbiology \& Biotechnology, 19: 811-815.

https://doi.org/10.1023/A:1026021424385
Wang, Y., Y. Fan, and J.-D. Gu, 2004. Dimethyl phthalate ester degradation by two planktonic and immobilized bacterial consortia. International Biodeterioration \& Biodegradation, 53: 93-101. https://doi.org/10.1016/j.ibiod.2003.10.005

WWP, Wen Wei Po, 2009. 90\% of people do not know the expansion on types of recyclables. http://paper.wenweipo.com/2009/02/01/HK0902010029.htm

Xu, X.R., H.B. Li, and J.-D. Gu, 2005a. Biodegradation of an endocrine-disrupting chemical di-n-butyl phthalate ester by Pseudomonas fluorescens B-1. International Biodeterioration \& Biodegradation, 55: 9-15. https://doi.org/10.1016/j.ibiod.2004.05.005

Xu, X.R., H.B. Li, and J.-D. Gu, 2005b. Degradation of n-butyl benzyl phthalate by Pseudomonas fluorescens B-1 isolated from mangrove sediment. Journal of Microbiology and Biotechnology, 15: 946-951.

Yan, S., Bala Subramanian, S., Tyagi, R.D., Surampalli, R.Y., 2008. Polymer production by bacterial strains isolated from activated sludge treating municipal wastewater. Water Science \& Technology, 57(4): 533-539. https://doi.org/10.2166/wst.2008.029

Yoshida, S., K. Hiraga, T. Takehana, I. Taniguchi, H. Yamaji, Y. Maeda, K. Toyohara, K. Miyamoto, Y. Kimura, K. Oda, 2016. A bacterium that degrades and assimilates poly(ethylene terephthalate). Science, 351: 1196-1199. https://doi.org/10.1126/science.aad6359

Zee, D.I.M.V.D., 2003. Evaluation and certification of compostable polymeric materials and products. In: Biopolymers (Volume 10) General Aspects and Special Applications (eds: Steinbüchel A.). Wiley-VCH, Weinheim, Germany, pp 393-408. https://doi.org/10.1002/3527600035.bpola013

Zheng, Y, Yanful, E.K., Bassi, A.S., 2005. A review of plastic waste biodegradation. Critical Reviews in Biotechnology, 25(4): 243250. https://doi.org/10.1080/07388550500346359 